\title{
Phenotypic and Functional Responses of Human Decidua Basalis Mesenchymal Stem/Stromal Cells to Lipopolysaccharide of Gram-Negative Bacteria
}

\author{
Ghofran Hasan Alshareef' \\ Afrah E Mohammed (iD) \\ Mohammed Abumaree $2,3, \dagger$ \\ Yasser S Basmaeil (iD ${ }^{2}$ \\ 'Biology Department, College of Science, \\ Princess Nourah Bint Abdulrahman \\ University, Riyadh, 84428, Saudi Arabia; \\ ${ }^{2}$ Stem Cell \& Regenerative Medicine \\ Department, King Abdullah International \\ Medical Research Center, King Saud bin \\ Abdulaziz University for Health Sciences, \\ Ministry of National Guard Health \\ Affairs, Riyadh, Saudi Arabia; ${ }^{3}$ College of \\ Science and Health Professions, King \\ Saud bin Abdulaziz University for Health \\ Sciences, King Abdulaziz Medical City, \\ Ministry of National Guard Health \\ Affairs, Riyadh, II48I, Saudi Arabia
}

†Prof. Mohammed Abumaree passed away on 26.07 .2019 .

\begin{abstract}
Introduction: Human decidua basalis mesenchymal stem cells (DBMSCs) are potential therapeutics for the medication to cure inflammatory diseases, like atherosclerosis. The current study investigates the capacity of DBMSCs to stay alive and function in a harmful inflammatory environment induced by high levels of lipopolysaccharide (LPS).

Methods: DBMSCs were exposed to different levels of LPS, and their viability and functional responses (proliferation, adhesion, and migration) were examined. Furthermore, DBMSCs' expression of 84 genes associated with their functional activities in the presence of LPS was investigated. Results: Results indicated that LPS had no significant effect on DBMSCs' adhesion, migration, and proliferation ( $24 \mathrm{~h}$ and $72 \mathrm{~h})(\mathrm{p}>0.05)$. However, DBMSCs' proliferation was significantly reduced at $10 \mu \mathrm{g} / \mathrm{mL}$ of LPS at $48 \mathrm{~h}(\mathrm{p}<0.05)$. In addition, inflammatory cytokines and receptors related to adhesion, proliferation, migration, and differentiation were significantly overexpressed when DBMSCs were treated with $10 \mu \mathrm{g} / \mathrm{mL}$ of LPS ( $<<0.05$ ). Conclusion: These results indicated that DBMSCs maintained their functional activities (proliferation, adhesion, and migration) in the presence of LPS as there was no variation between the treated DBMSCs and the control group. This study will lay the foundation for future preclinical and clinical studies to confirm the appropriateness of DBMSCs as a potential medication to cure inflammatory diseases, like atherosclerosis.
\end{abstract}

Keywords: placenta, endothelial cells, proliferation, adhesion, migration, real-time PCR

\section{Introduction}

Stem cell-based therapy and regenerative medicine have potentials to treat multiple diseases, including cardiovascular diseases (CVD), respiratory, neurological, skeletal, and autoimmune diseases. Moreover, what makes stem cells unique is their ability to release chemokines and receptors. These secretomes are needed for tissue regeneration, differentiation into various cell types, and self-renewal. ${ }^{1}$ There are two classes of stem cells. They can be categorized to adult stem cells and embryonic stem cells. ${ }^{2}$ Both have the capacity to differentiate to varied types of cells; therefore, they are suitable to use in regenerative medicine and cellular therapy. ${ }^{3}$ Varied types of stem cells have been tested and evaluated, examples of which are embryonic stem cells (ESCs), bone marrow stem cells (BMSCs), induced pluripotent stem cells (iPSCs), hematopoietic stem cells (HSCs), neural stem cells (NSCs), very small embryonic-like stem cells (VSELs), mesenchymal stem cells (MSCs), and others. ${ }^{4-6}$ Due to ethical controversies, applications of embryonic stem cells in clinical settings are restricted. ${ }^{6,7}$ 
Nevertheless, mesenchymal stem cells (MSCs) gained attentions in medicine and were applied to stem cellular therapies because they have several advantages over other stem cells. ${ }^{1}$ MSCs can directly differentiate when implanted in the damaged tissue. ${ }^{8-10}$ MSCs regulate paracrine effects as they secrete cytokines and growth factors, thus increase inflammatory reaction or tissue fibrosis at the site of injury, which then stimulate endogenous progenitor cells and new blood vessels formation (angiogenesis). ${ }^{11,12}$

Moreover, at the site of injury, damaged tissues release micro-environmental factors that are related to ischemia gradients and inflammation; MSCs respond well to those factors released at the site of inflammation and migrate to the affected area. ${ }^{13-15}$ Furthermore, MSCs can be found in various sources in the body including, bone marrow, muscles, umbilical cord, and other areas and have potential to differentiate and heal damaged tissues. ${ }^{16-18}$ MSCs can be isolated from decidua basalis, which is a thin layer on the maternal tissue of the human placenta. These MSCs are called decidua basalis mesenchymal stem cells (DBMSCs). ${ }^{19,22}$ They have several important functions in response to any injury and one of which is their capability to differentiate into numerous cell lineages, such as chondrocytes, adipocytes, and osteocytes. ${ }^{16,20}$ DBMSCs are subjected to oxidative stress mediators and inflammation due to their significant location. They are located near the maternal circulation in their placental vascular microenvironment niche. ${ }^{21-23}$ Recently, it has been shown that DBMSCs maintain their functions in oxidative stress environments induced by exposure to high levels of hydrogen peroxide $\left(\mathrm{H}_{2} \mathrm{O}_{2}\right) .{ }^{24}$ In addition, DBMSCs can preserve endothelial cell functions from damage resulting from exposure to elevated levels of oxidative stress inducers, including $\mathrm{H}_{2} \mathrm{O}_{2}$ and monocytes. ${ }^{23,25}$

Another form of oxidative stress or induced inflammatory microenvironment is the presence of endotoxins found on the outer membrane of gram-negative bacteria. Gram-negative organisms can be found in different locations on or in the human body. They are normally found in the gastrointestinal tract, genitourinary tract, and respiratory tract; and gram-negative aerobic and anaerobic bacteria colonize the human guts, which makes the human guts the largest reservoir of these microorganisms. ${ }^{26-29}$ Endotoxin or lipopolysaccharide (LPS) has potential roles in the structural integrity of the gram-negative bacterial walls. ${ }^{30}$ LPS is a complex glycolipid molecule. ${ }^{31,32}$ The LPS aids these organisms by shielding them from environmental impacts as well as antimicrobial or antibacterial products. ${ }^{30}$ Microorganisms produce LPS not only in infections but can leak LPS through the healthy and intact mucosal lines of the guts. ${ }^{33-36}$ Furthermore, the presence of harmful bacteria in the gut and LPS in the body is associated with several health conditions, such as inflammation, obesity, and metabolic disorder. ${ }^{31,32,37}$ It is well known that persistent inflammation can potentially develop many diseases in the body, such as autoimmune diseases, arthritis, allergic reactions, cancer, and vascular diseases. $^{35,38,39}$ Continuous vascular inflammation can develop atherosclerosis, which is a chronic coronary heart disease, and potentially lead to health problems like cardiovascular diseases. ${ }^{39-41}$

Low concentrations of LPS can induce vascular inflammation and endothelial injury, which is characterized by dysfunction and phenotypic changes, including overexpression of inflammatory and adhesion molecules. Typical dysfunction includes increased endothelial cell proliferation and increased permeability, which is characterized by increased barrier functional activity of the endothelial cell layer allowing plasma macromolecules, such as lipoproteins to enter the intimal layer more easily. ${ }^{42-44}$ LPS can be detected in the blood of healthy people at low concentrations ranging from 3 to $200 \mathrm{pg} / \mathrm{mL}^{.3-36}$ This level of LPS in healthy individuals has the potential to activate endothelial cells and cause inflammatory responses, thus can lead to atherosclerosis. ${ }^{35,45-47}$ Even if the individuals have healthy guts, low levels of LPS leak through the intact mucosa and end up in the splanchnic circulation. ${ }^{29,48,49}$

In this study, DBMSCs' functional responses in proinflammatory environments induced by LPS were evaluated. Several studies evaluated DBMSCs' responses to oxidative stress and found that under oxidative stress environment induced by $\mathrm{H}_{2} \mathrm{O}_{2}$ as well as monocytes, DBMSCs" functional activities including adhesion, proliferation, and migration were maintained. ${ }^{23,25}$ These significant results make DBMSCs as a suitable therapeutic target to repair endothelial cell injury and treat diseases caused by inflammation, such as atherosclerosis. Therefore, it was expected that DBMSCs would survive and function in harsh inflammatory environments induced by elevated levels of LPS.

In the current study, the main objective was to examine the ability of DBMSCs to survive in harsh inflammatory environments induced by high levels of LPS. Furthermore, the objectives were to study the consequences of LPS effects on DBMSCs' functional activities including adhesion, proliferation, and migration and to evaluate 
DBMSCs' expression of genes associated with inflammation and their functional activities.

\section{Materials and Methods Ethics of Experimentation}

This study was approved by the institutional research board (KAIMRC project \# RC15/110/R \& PNU Project \# IRBC/246/13) at King Abdullah International Medical Research Centre (KAIMRC)/King Abdulaziz Medical City, Riyadh, Saudi Arabia. All placentae were obtained with informed consent from healthy patients. The study was conducted in accordance with the Declaration of Helsinki.

\section{Isolation and Culture of DBMSCs}

MSCs have been isolated from the decidua basalis (DBMSCs) of human term placenta right after delivery, using a previously published method. ${ }^{19}$ DBMSCs were cultured in a complete DBMSCs culture medium in flask T25 [DMEM-F12 medium containing 10\% MSC FBS (mesenchymal stem cell certified fetal bovine serum, catalogue number 12-662-011, Life Technologies, Grand Island, USA), and antibiotics (100 $\mu \mathrm{g} / \mathrm{mL}$ streptomycin and $100 \mathrm{U} / \mathrm{mL}$ penicillin)]. Incubation of the cells at $37^{\circ} \mathrm{C}$ was performed in a humidified atmosphere consisting of $5 \% \mathrm{CO}_{2}$ and $95 \%$ air, in a cell culture incubator.

\section{Culture of DBMSCs with Different Concentrations of LPS}

DBMSCs were cultured in varied concentrations $(0,0.50,1$, $10,50,100,200 \mu \mathrm{g} / \mathrm{mL}$ ) of LPS (Catalogue number TLRLB5LPS, InvivoGen, USA). Experiments were completed in triplicate as well as repetition was performed independently with nine DBMSCs (passage 3) preparations.

\section{DBMSCs' Adhesion and Proliferation Assay Using the xCELLigence System} The xCELLigence system (RTCA-DP version; Roche Diagnostics, Mannheim, Germany) was used to evaluate the adhesion and proliferation of DBMSCs as this device automatically records and monitors real-time cell viability. The method used in this study was followed as previously published. $^{23,25,50-52}$ The experiments were initiated by addition of $100 \mu \mathrm{L}$ of complete DBMSC growth medium in 16-well culture plates (Catalogue number 05469813001, E-Plate 16, Roche Diagnostics) in presence and absence of different concentrations $(0,0.50,1,10,50,100,200 \mu \mathrm{g} / \mathrm{mL})$ of LPS. Plates were incubated at RT for $30 \mathrm{~min}$ then plates were placed in xCELLigence and instrument was set to blank. Plates were then removed from the machine. Next, the plates were seeded with $1 \times 10^{4}$ DBMSCs in each well and were incubated for $30 \mathrm{~min}$ at RT in the biosafety cabinet. The culture plates were then placed in the $\mathrm{xCELLigence} \mathrm{system} \mathrm{at} 37^{\circ} \mathrm{C}$ in a cell culture incubator, and the DBMSCs' index was automatically monitored every 15 minutes for $72 \mathrm{~h}$ and analyzed through RTCA software [version 1.2.1.1002]; the data for cell adhesion was recorded at $(2 \mathrm{~h})$ and proliferation was recorded at (24, 48 and 72 h). ${ }^{23,25,50-52}$ LPS treatments were changed every 12 hours. Each experiment has been done and repeated in triplicate.

\section{DBMSCs" Migration Assay Using xCELLigence System}

DBMSCs' migration has been tested by applying the xCELLigence system, and CIM-16-well plates (Catalogue number 05665825001, CIM-16, Roche Diagnostics $\mathrm{GmbH}$ ) as previously noted. ${ }^{23,25,50-52}$ The migration experiments have been started by addition of growth medium with $10 \%$ 'fetal bovine serum (FBS) in the presence and absence of different concentrations $(0$, $0.50,1,10,50,100,200 \mu \mathrm{g} / \mathrm{mL}$ ) of LPS in the lower chamber and free serum medium has been added in the upper chamber. The CIM-plate 16 was placed in the incubator at $37^{\circ} \mathrm{C}$ for 1 hour then the plate was placed in xCELLigence and instrument was set to blank. Next, the CIM-plate 16 was seeded with $1 \times 10^{4}$ DBMSCs in each well in the upper chamber and has been incubated for $30 \mathrm{~min}$. Then, plate was placed in the xCELLigence system and DBMSCs migration has been monitored automatically every $15 \mathrm{~min}$ for $24 \mathrm{~h}$ using the xCELLigence system and RTCA software [version 1.2.1.1002]; then data have been presented as a cell index value. ${ }^{23,25,50-52}$ Migration of DBMSCs with or without $10 \%$ FBS has been acted as a positive and negative control, respectively. Experiment has been done and repeated in triplicate.

\section{Gene Expression by Real-Time Polymerase Chain Reaction (RT-PCR)} DBMSCs' expression of $\mathrm{RT}^{2}$ profiler PCR Arrays 84 genes related to Human Inflammatory Cytokines and Receptors (Catalog number PAHS-011Z, Qiagen, Hilden, Germany) has been detected as previously 
published. ${ }^{19,23,24,52}$ There were two DBMSC samples: the control samples (untreated) and samples that were treated with LPS. LPS treatments were changed every 12 hours during the 48-hours incubation period. After $48 \mathrm{~h}$, the total RNA from DBMSCs [untreated DBMSCs, and DBMSCs treated with LPS] was extracted by using RNeasy Mini Kit (Qiagen, Hilden, Germany). Next, cDNA has been synthesized and utilized in a QuantiTect Reverse Transcription Kit (Qiagen, Hilden, Germany). Then, $20 \mu \mathrm{L}$ of the mixture was added to each well in the $\mathrm{RT}^{2}$ profiler PCR Arrays. The 96-well plate was then placed in the Thermal Cycle. The real-time polymerase chain reaction (RT- PCR) has been done in triplicate on the CFX96 realtime PCR detection system (BIO-RAD, California, USA). Then, the data were analyzed. ${ }^{19,23,24,52}$ The $\Delta \Delta^{-2}$ values have been then estimated to represent the findings as fold changes. The relative expression of internal controls (housekeeping genes) was used as provided in the $\mathrm{RT}^{2}$ profiler PCR Arrays kit. GAPDH was used as a housekeeping gene for humans as provided in the kit. Trials were performed in triplicate using DBMSCs obtained from three placentae independently.

\section{Statistical Analysis}

All the data shown in the bar graphs are presented as means \pm standard deviation (SD) of three independent experiments. To avoid bias, the experiments were performed three times independently. Using GraphPad Prism 9 , we analyzed the data sets of two experimental groups using $t$ - test, two tailed. Data deemed statistically significant if $p<0.05$.

\section{Results}

\section{Isolation and Culture of DBMSCs}

MSCs from the decidua basalis (DBMSCs) were successfully isolated from human term placentas and cultured in complete DBMSCs DMEM/F12 supplemented with penicillin at $100 \mu \mathrm{g} / \mathrm{mL}$ and streptomycin at $100 \mathrm{U} / \mathrm{mL}$ culture medium in a $\mathrm{T} 75$ cell culture flask, filter cap at $37^{\circ} \mathrm{C}$ in a cell culture incubator was previously described. ${ }^{25}$ At passage 2 , DBMSCs were positive for ( $>95 \%)$ MSC markers, and negative for haematopoietic markers (Figure 1). DBMSCs were able to differentiate into adipocytes, chondrocytes and osteocytes. These properties of DBMSCs were consistent with what we have reported previously. ${ }^{19}$ In all experiments, DBMSCs were used at passage 2.
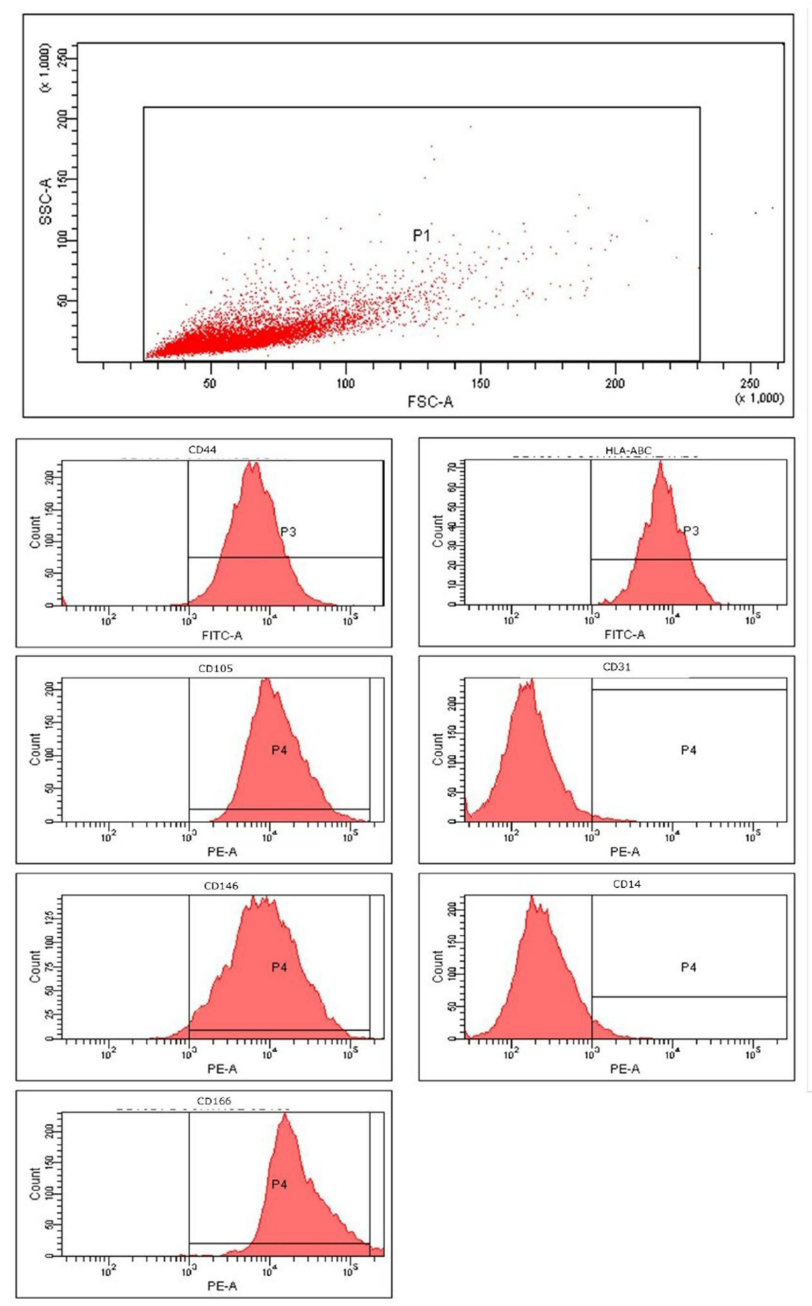

Figure I Characterization of decidua basalis mesenchymal stem/stromal cells (DBMSC's) for mesenchymal stem cell (MSC) markers. Flow cytometric analysis of DBMSCs for MSC markers (CD44, CD I05, CD I46, CD I66 and HLA-ABC); and MSC-negative markers (CD3I (endothelial cell) and CDI4 (macrophage/monocyte marker)).

\section{LPS Dose Response and Time Course for Experimental Standardization}

To assess the impact of LPS on DBMSCs' proliferation, DBMSCs have been cultured and treated at different concentrations of LPS and monitored for $72 \mathrm{~h}$ by using xCelligence system. After $24 \mathrm{~h}$, the proliferation of treated DBMSCs with concentrations of $0.50,1,10,50,100,200 \mu \mathrm{g} / \mathrm{mL}$ LPS showed no significant changes in comparison with the control $(\mathrm{p}>$ 0.05 ) (Figure 2B). After $48 \mathrm{~h}$, the proliferation of treated DBMSCs was significantly decreased at $10 \mu \mathrm{g} / \mathrm{mL}$ LPS ( $<<$ 0.05 ) while had no significant changes at $0.5,1,50,100$ and $200 \mu \mathrm{g} / \mathrm{mL}$ LPS $(\mathrm{p}>0.05)$ compared with the untreated DBMSCs (Figure 2C). Lastly, after $72 \mathrm{~h}$, the proliferation of treated DBMCSs with continuous exposure of LPS had no significant change in comparison with the untreated group 
A
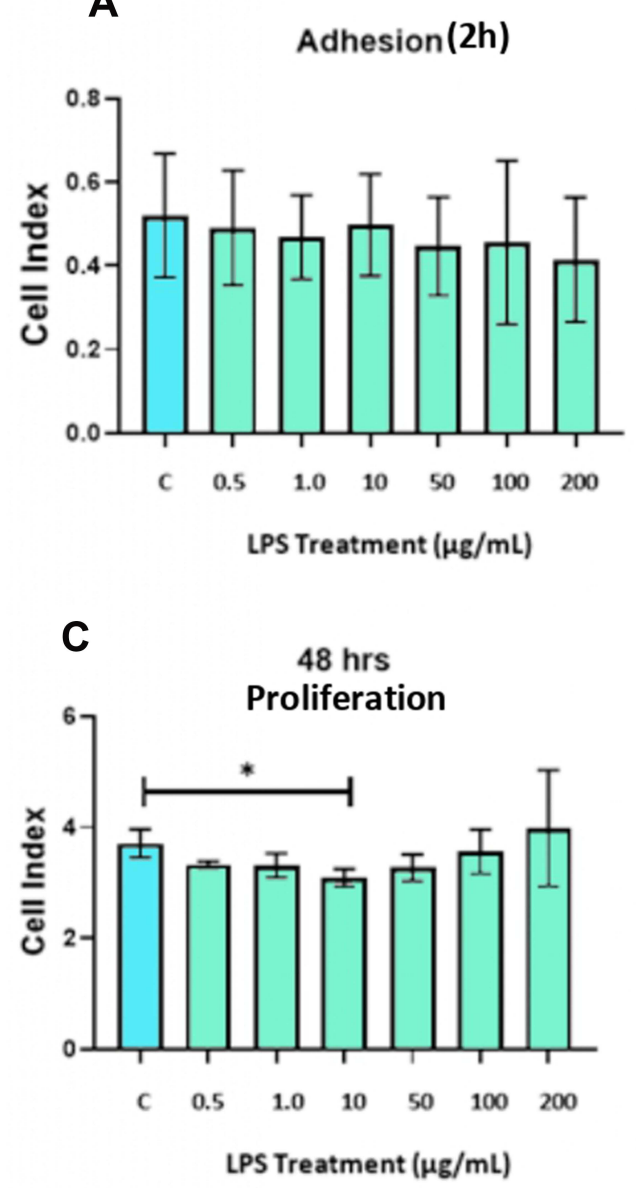

B
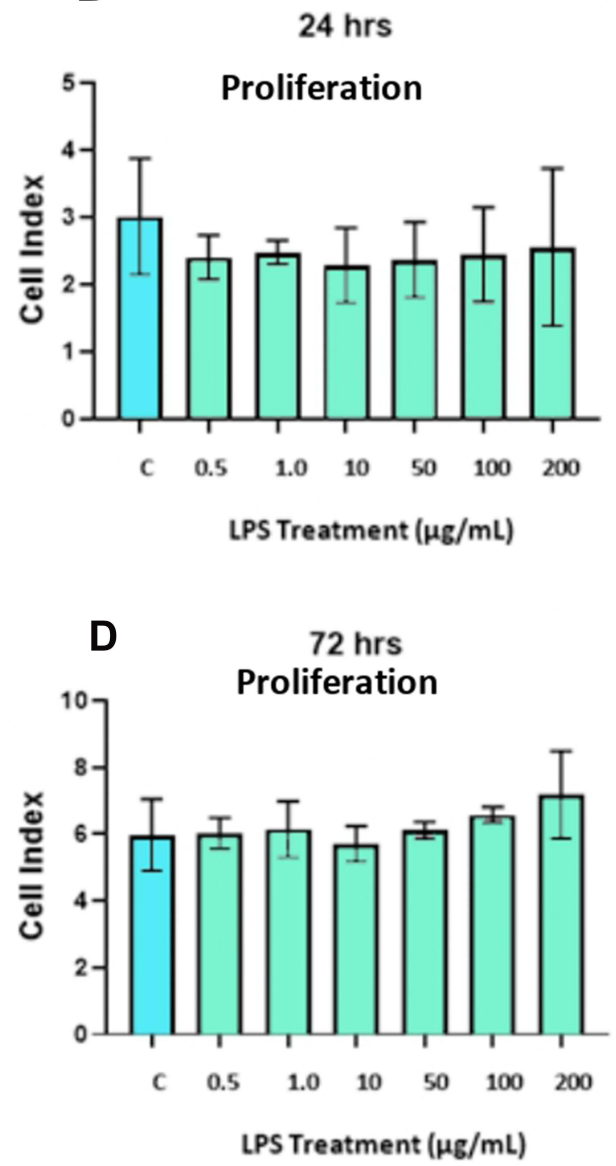

Figure 2 (A) LPS effects on DBMSCs' adhesion in comparison with the control group at $2 \mathrm{~h}$. (B-D) LPS effects on DBMSCs' proliferation in comparison with the control group at $24 \mathrm{~h}, 48 \mathrm{~h}$, and $72 \mathrm{~h}$. Experiments were performed three times independently, and the data are represented as mean \pm standard deviation. *Significant ( $<0.05$ ).

$(p>0.05)$ (Figure 2D). Based on the results above, the exposure time of $48 \mathrm{~h}$ and $10 \mu \mathrm{g} / \mathrm{mL}$ LPS was selected to evaluate the effects of LPS on the functions of DBMSCs (morphology, migration and gene analysis).

\section{LPS Effects on DBMSCs' Morphology}

To see the effect of LPS on DBMSCs' morphology, DBMSCs were cultured in $10 \mu \mathrm{g} / \mathrm{mL}$ LPS in complete DMEM/F12 for $48 \mathrm{~h}$. Microscopic analysis showed no change in the morphology of $10 \mu \mathrm{g} / \mathrm{mL}$ LPS treated DBMSCs in compared with the untreated DBMSCs at 24 and $48 \mathrm{~h}$ (Figure 3 ). The viability of DBMSCs treated with $10 \mu \mathrm{g} / \mathrm{mL}$ LPS was $>95 \%$.

\section{LPS Effects on DBMSCs' Migration}

Under continuous exposure to LPS, the migration of DBMSCs in the upper chamber of the migration plates was examined and monitored by the xCELLigence system for $24 \mathrm{~h}$. After $24 \mathrm{~h}$, no significant impact of LPS on DBMSCs' migration ( $p>0.05$ ) was stated compared to the control (Figure 4).

\section{LPS Modulates Various Gene Expression Related to Inflammatory Cytokines and Receptors in DBMSC}

Total RNA was extracted from untreated and $10 \mu \mathrm{g} / \mathrm{mL}$ LPS treated DBMSCs for $48 \mathrm{~h}$. the gene expression of inflammatory cytokines and chemokines was analyzed and assessed using RT-PCR. Then the $\Delta \Delta^{-2}$ values were used to yield the fold change values. In Tables 1-3, as well as Figure 5, results indicated that LPS influenced and modulated DBMSCs' expression of various genes that are related to human inflammatory cytokines and receptors. In Table 4 and Figure 6 results showed cytokines and receptors that mediate DBMSCs' functional responses, such as proliferation, migration, and differentiation were 


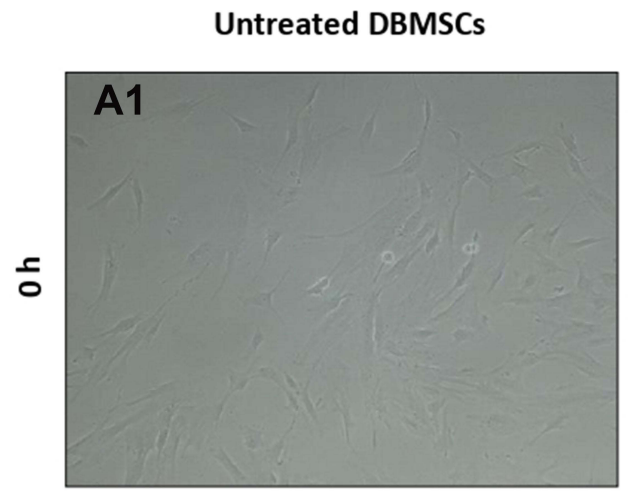

DBMSCs $+10 \mu \mathrm{g} / \mathrm{mL}$ LPS
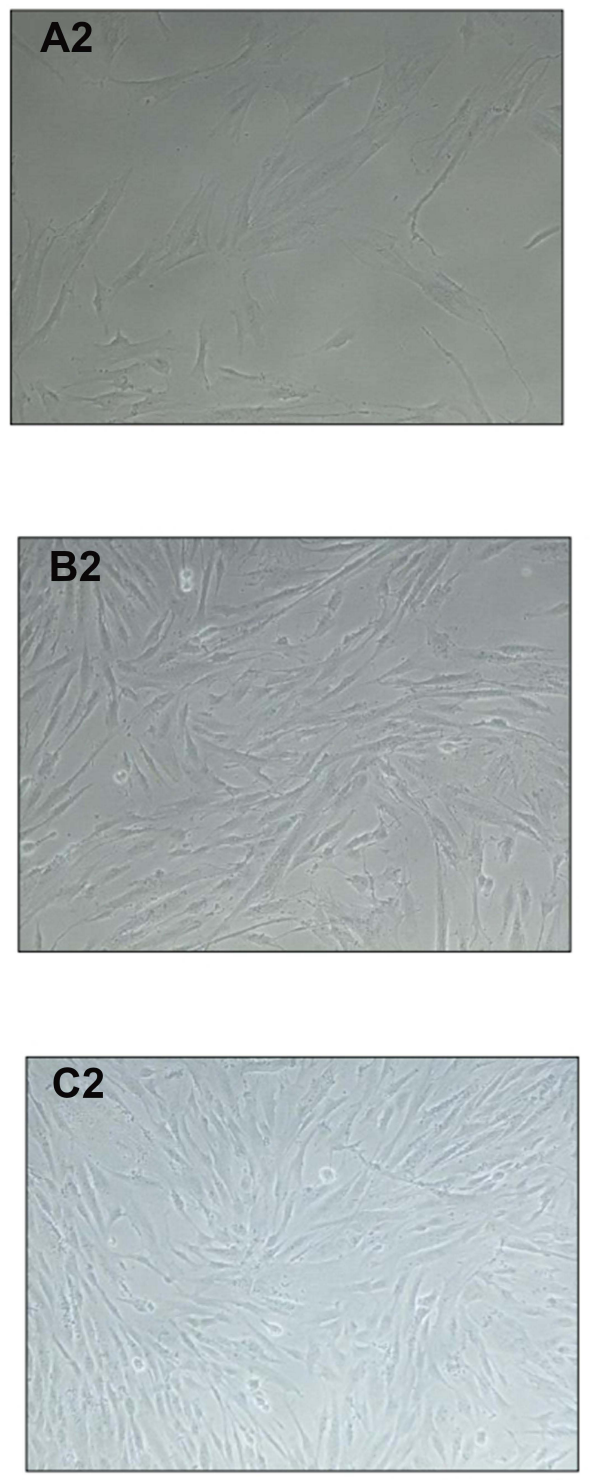

Figure 3 (AI and A2) Untreated DBMSCs vs DBMSCs treated with continuous exposure of $10 \mu g / \mathrm{mL}$ LPS on the first hour when treatment was initiated at $60 \%$ confluency (100x magnification). (BI and B2) Untreated DBMSCs vs DBMSCs treated with continuous exposure of $10 \mu g / \mathrm{mL}$ LPS after $24 \mathrm{~h}$ of incubation period at $80 \%$ confluency (I00× magnification). (CI and C2) Untreated DBMSCs vs DBMSCs treated with continuous exposure of $10 \mu \mathrm{g} / \mathrm{mL} \mathrm{LPS}$ after $48 \mathrm{~h}$ of incubation period at $90 \%$ confluency (I00x magnification).

overexpressed $(p<0.05)$. In Table 5 and Figure 7 genes that mediate DBMSCs' migration properties such as CXCR2 and CXCL12 were down regulated in the presence of LPS $(p<0.05)$. There are other genes that were down regulated in the presence of LPS. However, they are not necessarily related to DBMSCs' functions (Table 5). The number of overexpressed genes that are related to DBMSCs' functional activities (proliferation, adhesion, and migration) were 31 genes $(p<0.05)$ (Table 4). On the other hand, the number of downregulated genes were
33 genes, 31 of which are not necessarily related to DBMSCs' functions while two of the genes were related to DBMSCs' migration properties (CXCR2 and CXCL12) $(p<0.05)$ (Table 5). Biological activities of the genes in the following Tables 1-5 were obtained from GeneBank via https via www.ncbi.nlm.nih.gov/nuccore/.

\section{Discussion}

Mesenchymal stem cells have gained a lot of attention for their therapeutic agent properties over the past decade. 


\section{Migration}

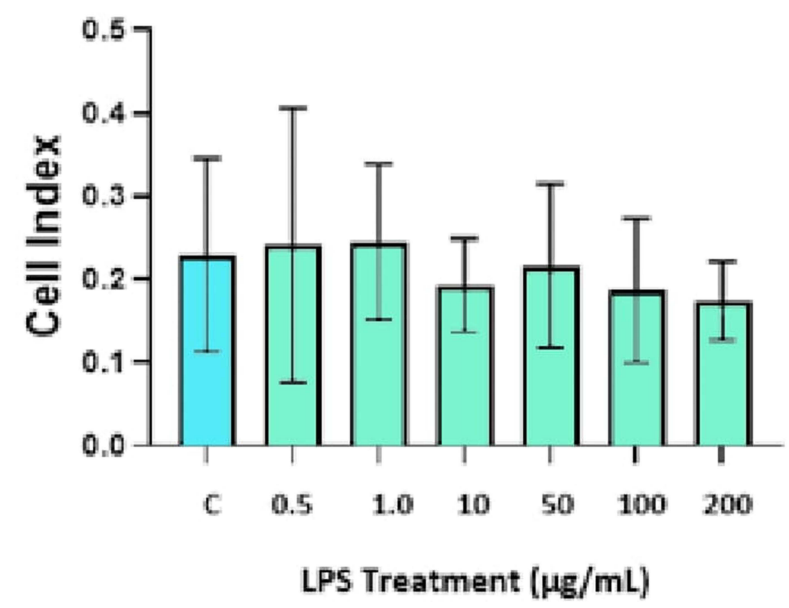

Figure 4 LPS effects on DBMSCs' migration in comparison with the control group at $24 \mathrm{~h}$. Experiments were performed three times independently, and the data are represented as mean \pm standard deviation.

Moreover, MSCs have properties to regenerate and differentiate into mesodermal lineages (adipocytes, osteoblasts, and chondroblasts) as well as neuroectodermic lineages (neurons or alveolar endothelial cells). ${ }^{53-55}$ In addition, MSCs could be differentiated into non-mesodermal lineages (eg, cardiomyocytes, hepatocytes, or epithelial cells). ${ }^{56-58}$ MSCs could be originated from the bone marrow; however, they have been isolated from varied origins in humans, such as adipose tissue, hair follicles, umbilical cords, placentas, muscle, peripheral blood, amniotic fluid, and other organs, such as brain, liver, or lung. ${ }^{16,54,59,60}$ Moreover, MSCs have different sources and their multilineage differentiations are not the only potentials that make MSCs special. MSCs have potential to migrate to sites of inflammation in which they stimulate tissue regeneration by releasing paracrine factors as well as differentiating and replacing damaged tissues or cells. ${ }^{61}$ Not only MSCs have the capabilities to heal but they also are involved in paracrine signaling and cell-cell communication. ${ }^{62}$ Furthermore, MSCs have the ability to interact with the host niche at the site of injury or inflammation and promote the following functions: MSCs can inhibit the immune system, promote cell survival, and/or form new blood vessels via angiogenesis by releasing factors, such as IL-6. ${ }^{61,63}$

There are several impacts that influence the successive implications of MSCs in clinical settings when cell therapy is introduced to the patients. As a result of these challenges, $99 \%$ of MSCs will die a few days after transplantations, thus resulting in unsuccessful applications of this approach. $^{64-73}$ These challenges can result from MSCs isolation techniques that will result in uncontrolled cell quality, or invasive isolation processes as there are several ways and approaches to isolate MSCs from tissues, loss of MSCs potency, limited lifespan of MSCs, or loss of MSCs properties when cells are expanding or proliferating in vitro. Other challenges could be initiated when MSCs are transplanted in the recipients' tissues or organs, such as stressful condition (oxidative stress, inflammation, radiation, and chemotherapy). ${ }^{64-73}$ Interestingly, MSCs that are derived and isolated from maternal decidua basalis tissue of human placenta have unique phenotypic characteristics and can withstand environments that are highly stressful because pregnancy is a highly stressful condition in which the decidua basalis tissue is exposed to high amounts of oxidative stress or inflammatory environment. ${ }^{22-24,74-76}$ Previously, $\mathrm{H}_{2} \mathrm{O}_{2}$ and monocytes were introduced to DBMSCs, and results demonstrated that DBMSCs maintained their phenotypic properties and functions. ${ }^{23}$ LPS is another form of inflammatory environment inducer and in this study, LPS was introduced to DBMSCs, and their phenotypic functions were monitored and analyzed.

According to the International Society for Cellular Therapy (ISCT), for MSCs to be used as a therapeutic agent, they must meet the minimal criteria for defining their multipotent function; one of which is the MSCs ability to adhere to plastic surfaces when grown in vitro. ${ }^{77}$ In the current study, DBMSCs were treated with LPS without preconditioning. Results showed that after $2 \mathrm{~h}$, LPS had no significant effect on DBMSCs' adhesion $(p>0.05)$. Khatlani et $\mathrm{al}^{24}$ studied the multipotent properties of DBMSCs when they were preconditioned with $\mathrm{H}_{2} \mathrm{O}_{2}$. The authors found that DBMSCs' adhesion in presence of $\mathrm{H}_{2} \mathrm{O}_{2}$ was significantly increased when they were preconditioned with $\mathrm{H}_{2} \mathrm{O}_{2}$ for $72 \mathrm{~h}(p<0.05)$ while DBMSCs' adhesion that were not $\mathrm{H}_{2} \mathrm{O}_{2}$-preconditioned remained unchanged $(p>0.05)$. Same trend of observation regarding DBMSCs' adhesion when subjected to a stressful condition without preconditioning was noted. Previous studies found that preconditioned MSCs, such as DBMSCs and BMMSCs with oxidative stress mediators (eg, $\mathrm{H}_{2} \mathrm{O}_{2}$, glucose, hypoxia) enhanced the MSCs' performance. ${ }^{24,76,78}$ Several studies claimed that the possible reason why MSCs' performances were enhanced when preconditioned with hypoxia or oxidative stress could be due to activation of paracrine or pro-angiogenic pathways, so they could survive and adapt to oxidative stress environments. ${ }^{78-82}$ 
Table I LPS Effects on DBMSCs' Gene Expression of Cytokines and Cytokine Receptors.

\begin{tabular}{|c|c|c|c|c|c|c|}
\hline Gene & Gene Full Name & $\begin{array}{l}\text { Control } \\
\text { Mean } \Delta \Delta^{-2} \\
\text { Value }\end{array}$ & \multicolumn{2}{|c|}{$\begin{array}{l}10 \mu g / m L \text { LPS } \\
\text { Mean } \Delta \Delta^{-2} \\
\text { Value }\end{array}$} & $\begin{array}{c}\text { Fold Change Control } \\
\text { vs } 10 \mu g / m L \text { LPS } \\
P<0.05\end{array}$ & Biological Activity \\
\hline \multicolumn{7}{|c|}{ A: Results of Fold Change That are $>2.0$ in Control vs $10 \mu \mathrm{g} / \mathrm{mL}$ LPS $(p<0.05)$} \\
\hline CCLI 7 & Chemokine (C-C motif) ligand 17 & I & 18.32 & 4.20 & $\uparrow^{*}$ & Migration property \\
\hline CCL23 & Chemokine (C-C motif) ligand 23 & I & 5.10 & 2.35 & $\uparrow$ & Migration property \\
\hline CXCLIO & Chemokine ( $\mathrm{C}-\mathrm{X}-\mathrm{C}$ motif) ligand $\mathrm{I} 0$ & I & 8480.52 & 13.05 & $\uparrow$ & Migration property \\
\hline CXCLI & $\begin{array}{c}\text { Chemokine (C-X-C motif) ligand I } \\
\text { (melanoma growth stimulating activity, } \\
\text { alpha) }\end{array}$ & I & 15.62 & 3.97 & $\uparrow$ & Migration property \\
\hline CXCLII & Chemokine (C-X-C motif) ligand II & I & 5.86 & 2.55 & $\uparrow$ & Anti-inflammatory \\
\hline CX3CRI & Chemokine (C-X3-C motif) receptor I & I & 590.76 & 9.21 & $\uparrow$ & Migration property \\
\hline CXCL2 & Chemokine (C-X-C motif) ligand 2 & I & 4.15 & 2.05 & $\uparrow$ & Migration property \\
\hline \multicolumn{7}{|c|}{ B: Results of Fold Change That are $<2.0$ in Control vs $10 \mu \mathrm{g} / \mathrm{mL}$ LPS $(p<0.05)$} \\
\hline CCLI5 & Chemokine (C-C motif) ligand 15 & I & 1.23 & 0.29 & $\uparrow^{*}$ & \\
\hline CCL24 & Chemokine ( $\mathrm{C}-\mathrm{C}$ motif) ligand 24 & 1 & 1.08 & 0.11 & $\uparrow$ & \\
\hline CCL26 & Chemokine ( $\mathrm{C}-\mathrm{C}$ motif) ligand 26 & I & 1.43 & 0.51 & $\uparrow$ & \\
\hline CCL7 & Chemokine ( $\mathrm{C}-\mathrm{C}$ motif) ligand 7 & I & 1.24 & 0.31 & $\uparrow$ & \\
\hline CXCL3 & Chemokine ( $\mathrm{C}-\mathrm{X}-\mathrm{C}$ motif) ligand 3 & I & 2.06 & 1.05 & $\uparrow$ & Migration property \\
\hline CXCL5 & Chemokine (C-X-C motif) ligand 5 & I & 1.21 & 0.27 & $\uparrow$ & Migration property \\
\hline CXCL6 & $\begin{array}{l}\text { Chemokine (C-X-C motif) ligand } 6 \\
\text { (granulocyte chemotactic protein 2) }\end{array}$ & I & 1.16 & 0.21 & $\uparrow$ & \\
\hline CCR4 & Chemokine (C-C motif) receptor 4 & I & 3.12 & 1.64 & $\uparrow$ & Migration property \\
\hline CCR5 & Chemokine ( $\mathrm{C}-\mathrm{C}$ motif) receptor 5 & I & 1.06 & 0.08 & $\uparrow$ & \\
\hline CXCRI & Chemokine ( $\mathrm{C}-\mathrm{X}-\mathrm{C}$ motif) receptor I & I & 1.09 & 0.12 & $\uparrow$ & Migration property \\
\hline CCLII & Chemokine ( $\mathrm{C}-\mathrm{C}$ motif) ligand II & I & 0.03 & -5.08 & $\downarrow^{*}$ & Anti-inflammatory \\
\hline CCLI3 & Chemokine ( $\mathrm{C}-\mathrm{C}$ motif) ligand I3 & I & 0.17 & -2.52 & $\downarrow$ & $\begin{array}{l}\text { Immunoregulatory and } \\
\text { inflammatory processes }\end{array}$ \\
\hline CCL20 & Chemokine ( $\mathrm{C}-\mathrm{C}$ motif) ligand 20 & I & 0.16 & -2.62 & $\downarrow$ & $\begin{array}{l}\text { Immunoregulatory and } \\
\text { inflammatory processes }\end{array}$ \\
\hline CXCLI2 & Chemokine ( $\mathrm{C}-\mathrm{X}-\mathrm{C}$ motif) ligand 12 & 1 & 0.11 & -3.20 & $\downarrow$ & Migration property \\
\hline CXCLI3 & Chemokine ( $\mathrm{C}-\mathrm{X}-\mathrm{C}$ motif) ligand 13 & I & 0.02 & -5.47 & $\downarrow$ & $\begin{array}{l}\text { B lymphocyte } \\
\text { chemoattractant }\end{array}$ \\
\hline CXCL9 & Chemokine (C-X-C motif) ligand 9 & I & 0.15 & -2.77 & $\downarrow$ & $\begin{array}{l}\text { Immunoregulatory and } \\
\text { inflammatory processes }\end{array}$ \\
\hline CCR3 & Chemokine ( $\mathrm{C}-\mathrm{C}$ motif) receptor 3 & I & 0.13 & -2.94 & $\downarrow$ & \\
\hline CXCR2 & Chemokine ( $\mathrm{C}-\mathrm{X}-\mathrm{C}$ motif) receptor 2 & I & 0.11 & -3.16 & $\downarrow$ & Migration property \\
\hline
\end{tabular}

(Continued) 
Table I (Continued).

\begin{tabular}{|c|c|c|c|c|c|c|}
\hline Gene & Gene Full Name & $\begin{array}{l}\text { Control } \\
\text { Mean } \Delta \Delta^{-2} \\
\text { Value }\end{array}$ & $\begin{array}{r}10 \mu g / \\
\text { Mea } \\
V\end{array}$ & $\begin{array}{l}\text { LPS } \\
\Delta \Delta^{-2} \\
\text { le }\end{array}$ & $\begin{array}{c}\text { Fold Change Control } \\
\text { vs } 10 \mu g / m L \text { LPS } \\
P<0.05\end{array}$ & Biological Activity \\
\hline CXCLI & Chemokine ( $\mathrm{C}-\mathrm{X} 3-\mathrm{C}$ motif) ligand I & 1 & 0.30 & -1.75 & $\downarrow$ & Inflammation \\
\hline CCRI & Chemokine (C-C motif) receptor I & I & 0.55 & -0.85 & $\downarrow$ & $\begin{array}{c}\text { Inflammatory } \\
\text { responses }\end{array}$ \\
\hline CCR6 & Chemokine (C-C motif) receptor 6 & 1 & 0.42 & -1.25 & $\downarrow$ & \\
\hline CCR8 & Chemokine (C-C motif) receptor 8 & I & 0.90 & -0.15 & $\downarrow$ & \\
\hline
\end{tabular}

Notes: $*=$ Upregulation. $*$ = Downregulation.

DBMSCs were treated with $10 \mu g / m L$ LPS $(p<0.05)$ and compared to the untreated DBMSCS for $72 \mathrm{~h}$.

Next, DBMSCs' ability to proliferate in the presence of an pro-inflammatory mediator, such as LPS is important to evaluate DBMSCs' potential use in cellular therapies. Current results showed that LPS had no significant effect on DBMSCs' proliferation during the $24 \mathrm{~h}$ and $72 \mathrm{~h}(p>0.05)$. However, at $48 \mathrm{~h}$, LPS significantly reduced DBMSCs' proliferation at $10 \mu \mathrm{g} / \mathrm{mL}$ LPS $(p<0.05)$ while had no significant changes on DBMSCs' proliferation at $0.5,1,50,100$, and $20,010 \mu \mathrm{g} / \mathrm{mL}$ LPS $(p>0.05)$. Khatlani et $\mathrm{al}^{24}$ reported a similar finding in which the authors evaluated the effect of $\mathrm{H}_{2} \mathrm{O}_{2}$ on DBMSCs' proliferation. After $24 \mathrm{~h}$ and $48 \mathrm{~h}, 1,5,25$, 50,100 , and $200 \mu \mathrm{M}$ of $\mathrm{H}_{2} \mathrm{O}_{2}$ had no significant effect on DBMSCs' proliferation ( $p>0.05$ ); however, DBMSCs' proliferation was significantly reduced when they were treated with higher concentration of $\mathrm{H}_{2} \mathrm{O}_{2}(400$ and $600 \mu \mathrm{M})(p<$ $0.05)$. A study conducted by Kurte et $\mathrm{al}^{83}$ found that MSC phenotypes can change depending on how long they were exposed to LPS. It was found that MSCs exerted different phenotypes when they were exposed to LPS at $1 \mathrm{~h}$ than when they were exposed to LPS at $24 \mathrm{~h}$ and $48 \mathrm{~h}$. The authors claimed that the molecular explanation behind this phenomenon is still unclear.

In addition, results showed that IL-9 was overexpressed when DBMSCs were treated with $10 \mu \mathrm{g} / \mathrm{mL}$ of LPS. However, Durand et $\mathrm{al}^{84}$ found that LPS had no significant changes on IL- 9 secretion by BMSCs. The variations in IL-9 expression in the presence of LPS could be related to the different types of MSCs investigated and treatment conditions. IL-9 has many important functions; it modulates and regulates several hematopoietic cells, it prevents programmed cell death (apoptosis), and most importantly it stimulates cell proliferation. ${ }^{85}$ In a study conducted by Sun et $\mathrm{al}^{86}{ }^{86}$ the authors found that IL-9 played an important role in trophoblast cells angiogenesis; and reduction of IL-9 led to reduction of angiogenesis in trophoblast cells. In addition, IL1-B is a pro-inflammatory cytokine that has a great effect on MSCs proliferative properties. ${ }^{87-89}$ In current study, IL1B was overexpressed when DBMSCs were treated with 10 $\mu \mathrm{g} / \mathrm{mL}$ LPS. This finding correlated with a study conducted by Cui et $\mathrm{al}^{90}$ in which the authors found that several proinflammatory cytokines, such as IL1-B that were secreted by MSCs in the lungs were upregulated under exposure of chronic airway LPS. However, additional future mechanistic study is necessary to confirm this.

To yield a successful outcome for MSCs' clinical applications, MSCs need to be able to migrate to the sites of inflammation (target tissues). ${ }^{77}$ Results showed that LPS had no significant effect on DBMSCs' migration $(p>0.05)$ after 24-h incubation in the upper chamber of the migration plates. Similarly, Khatlani et $\mathrm{al}^{24}$ found that DBMSCs' migration in the presence of $\mathrm{H}_{2} \mathrm{O}_{2}$ had no significant effect $(p>0.05)$ while preconditioning DBMSCs with $\mathrm{H}_{2} \mathrm{O}_{2}$ yielded a significant increase in DBMSCs' migration $(p<$ 0.05). Chemoattractant signals can influence the rate of MSCs' migration to the damaged tissue; and MSCs' migration is mediated by many chemokine ligands and receptors, such as CXCL12, CCR4, and others. These chemokines and receptors have an important effect in MSCs' inflammatory responses and migration. ${ }^{91-96}$ Hereby, when DBMSCs were treated with $10 \mu \mathrm{g} / \mathrm{mL}$ of LPS, various chemokines and receptors, including CCL23, CXCL10, CXCL11, CX3CR1, CXCL2, CCR4, CXCL3, and CXCL5 were significantly overexpressed $(p<0.05)$. Previous studies noted that DBMSCs alone expressed CC, CXC and various chemokines and receptors family members, such as CCL1, CCL2, CCL21 and others. Nevertheless, DBMSCs alone did not express certain chemokines and receptors, such as CXCR1 and CX3CR1. ${ }^{19}$ Yet, in the presence of LPS, DBMSCs 
Table 2 LPS Effects on DBMSCs' Gene Expression of Interleukins and Interleukin Receptors.

\begin{tabular}{|c|c|c|c|c|c|c|}
\hline Gene & Gene Full Name & $\begin{array}{l}\text { Control } \\
\text { Mean } \Delta \Delta^{-2} \\
\text { Value }\end{array}$ & $\begin{array}{c}10 \mu g / m L \text { LPS } \\
\text { Mean } \Delta \Delta^{-2} \\
\text { Value }\end{array}$ & $\begin{array}{l}\text { Fold Change Control vs } \\
\text { 10 } \mathrm{\mu g} / \mathrm{mL} \text { LPS } P<0.05\end{array}$ & & Biological Activity \\
\hline \multicolumn{7}{|c|}{ A: Results of Fold Change That are $>2.0$ in Control vs $10 \mu \mathrm{g} / \mathrm{mL}$ LPS $(p<0.05)$} \\
\hline ILI 7A & Interleukin I7A & I & $17590 \mid .84$ & 17.42 & $\uparrow^{*}$ & Pro-inflammatory \\
\hline ILIB & Interleukin I, beta & I & 4.30 & 2.10 & $\uparrow$ & Pro-inflammatory \\
\hline IL9 & Interleukin 9 & 1 & 1659291.13 & 20.66 & $\uparrow$ & Pro-inflammatory \\
\hline ILIRI & Interleukin I receptor, type I & 1 & 496.33 & 8.96 & $\uparrow$ & Pro-inflammatory \\
\hline \multicolumn{7}{|c|}{ B Results of Fold Change That are $<2.0$ in Control vs $10 \mu \mathrm{g} / \mathrm{mL}$ LPS $(p<0.05)$} \\
\hline IL8 & Interleukin 8 & I & 2.38 & 1.25 & $\uparrow^{*}$ & Pro-inflammatory \\
\hline ILIA & Interleukin I, alpha & I & 1.22 & 0.29 & $\uparrow$ & \\
\hline ILIRN & $\begin{array}{l}\text { Interleukin I receptor } \\
\text { antagonist }\end{array}$ & 1 & 1.05 & 0.08 & $\uparrow$ & \\
\hline IL7 & Interleukin 7 & 1 & 1.88 & 0.91 & $\uparrow$ & \\
\hline ILI3 & Interleukin 13 & 1 & 0.13 & -2.91 & $\downarrow^{*}$ & Anti-inflammatory \\
\hline ilLI5 & Interleukin I5 & I & 0.12 & -3.02 & $\downarrow$ & $\begin{array}{l}\text { T and natural killer cell } \\
\text { activation and proliferation }\end{array}$ \\
\hline IL27 & Interleukin 27 & I & 0.18 & -2.44 & $\downarrow$ & $\begin{array}{c}\text { Pro- and anti-inflammatory } \\
\text { properties }\end{array}$ \\
\hline IL5 & $\begin{array}{l}\text { Interleukin } 5 \text { (colony- } \\
\text { stimulating factor, } \\
\text { eosinophil) }\end{array}$ & 1 & 0.12 & -3.08 & $\downarrow$ & $\begin{array}{l}\text { B cells and eosinophils } \\
\text { growth and differentiation }\end{array}$ \\
\hline IL9R & Interleukin 9 receptor & I & 0.13 & -2.94 & $\downarrow$ & \\
\hline ILIORB & $\begin{array}{c}\text { Interleukin } 10 \text { receptor, } \\
\text { beta }\end{array}$ & 1 & 0.60 & -0.75 & $\downarrow$ & \\
\hline IL5RA & $\begin{array}{c}\text { Interleukin } 5 \text { receptor, } \\
\text { alpha }\end{array}$ & I & 0.75 & -0.41 & $\downarrow$ & \\
\hline
\end{tabular}

Notes: $*=$ Upregulation. $*=$ Downregulation.

DBMSCs were treated with $10 \mu \mathrm{g} / \mathrm{mL}$ LPS $(\mathrm{p}<0.05)$ and compared to the untreated DBMSCS for $72 \mathrm{~h}$.

significantly overexpressed CXCR1 and CX3CR1 $(p<0.05)$. However, CXCL12 was downregulated in the presence of LPS, and this result is correlated to a study conducted by Wobus et al. ${ }^{97}$ In their study, the authors tested CXCL12 secretion and expression by MSCs in breast cancer cells in comparison to non-tumorigenic breast epithelial cells. They found that CXCL12 was downregulated in the breast cancer cells while the control group had no effect of CXCL12 secretion. The authors explained that cancer cells paracrine factors or small molecules derived from cancer or tumor cells could have the possible effect on this observation. ${ }^{97}$ In the current study, LPS could be the reason why CXCL12 was downregulated. It was found that overexpression of certain chemokine ligands or receptors, such as the chemokine receptor CXCR2, or chemokine ligands CXCL1, CXCL3, and CXCL5 can enhance MSCs' migration to the target tissue and promote cell survival. ${ }^{98}$ In Shen et al study, ${ }^{98}$ MSCs were exposed to radiation/chemical-induced oral mucositis and the authors found that CXCR2 level was overexpressed after radiation and was peaked at day 7 and eventually started to decline. In addition, CXCL1, CXCL3, and CXCL5 were upregulated after exposure to radiation. However, in the presence of LPS, CXCR2 was significantly downregulated. Different trends in oxidative stress inducers 
Table 3 LPS Effects on DBMSCs' Gene Expression of Other Cytokines and Other Cytokine Receptors.

\begin{tabular}{|c|c|c|c|c|c|c|}
\hline Gene & Gene Full Name & $\begin{array}{l}\text { Control } \\
\text { Mean } \Delta \Delta^{-2} \\
\text { Value }\end{array}$ & $\begin{array}{l}10 \mu g / m L \text { LPS } \\
\text { Mean } \Delta \Delta^{-2} \\
\text { Value }\end{array}$ & \multicolumn{2}{|c|}{$\begin{array}{l}\text { Fold Change } \\
\text { Control vs } 10 \mu g / \\
\text { mL LPS } P<0.05\end{array}$} & Biological Activity \\
\hline \multicolumn{7}{|c|}{ A: Results of Fold Change That are $>2.0$ in Control vs $10 \mu \mathrm{g} / \mathrm{mL}$ LPS $(p<0.05)$} \\
\hline BMP2 & Bone morphogenetic protein 2 & I & 8.72 & 3.12 & $\uparrow^{*}$ & Differentiation properties \\
\hline \multicolumn{7}{|c|}{ B: Results of Fold Change That are $<2.0$ in Control vs $10 \mu \mathrm{g} / \mathrm{mL}$ LPS $(p<0.05)$} \\
\hline CD4OLG & CD40 ligand & I & 1.43 & 0.51 & $\uparrow^{*}$ & \\
\hline CSF2 & $\begin{array}{l}\text { Colony-stimulating factor } 2 \\
\text { (granulocyte-macrophage) }\end{array}$ & I & 2.03 & 1.02 & $\uparrow$ & \\
\hline CSF3 & $\begin{array}{c}\text { Colony-stimulating factor } 3 \\
\text { (granulocyte) }\end{array}$ & I & 3.88 & 1.96 & $\uparrow$ & \\
\hline TNFSF4 & $\begin{array}{l}\text { Tumor necrosis factor (ligand) } \\
\text { superfamily, member } 4\end{array}$ & 1 & 1.09 & 0.13 & $\uparrow$ & \\
\hline TNFRSFI IB & $\begin{array}{l}\text { Tumor necrosis factor receptor } \\
\text { superfamily, member IIb }\end{array}$ & I & 1.37 & 0.46 & $\uparrow$ & \\
\hline AIMPI & $\begin{array}{c}\text { Aminoacyl tRNA synthetase } \\
\text { complex-interacting multifunctional } \\
\text { protein I }\end{array}$ & 1 & 0.65 & -0.62 & $*$ & Inflammatory properties \\
\hline CSFI & $\begin{array}{l}\text { Colony-stimulating factor I } \\
\text { (macrophage) }\end{array}$ & 1 & 0.67 & -0.58 & $\downarrow$ & Pro-inflammatory responses \\
\hline IFNG & Interferon, gamma & 1 & 0.87 & -0.21 & $\downarrow$ & Immunoregulatory functions \\
\hline LTB & $\begin{array}{l}\text { Lymphotoxin beta (TNF superfamily, } \\
\text { member } 3 \text { ) }\end{array}$ & 1 & 0.40 & -1.31 & $\downarrow$ & Inflammatory responses \\
\hline MIF & $\begin{array}{c}\text { Macrophage migration inhibitory } \\
\text { factor (glycosylation-inhibiting factor) }\end{array}$ & 1 & 0.74 & -0.43 & $\downarrow$ & $\begin{array}{l}\text { Immunoregulation and } \\
\text { inflammation }\end{array}$ \\
\hline NAMPT & $\begin{array}{c}\text { Nicotinamide } \\
\text { phosphoribosyltransferase }\end{array}$ & 1 & 0.95 & -0.07 & $\downarrow$ & $\begin{array}{c}\text { Metabolism, stress response } \\
\text { and aging }\end{array}$ \\
\hline OSM & Oncostatin M & I & 0.95 & -0.07 & $\downarrow$ & Growth regulator \\
\hline SPPI & Secreted phosphoprotein I & 1 & 0.44 & -1.18 & $\downarrow$ & \\
\hline TNFSFI3B & $\begin{array}{l}\text { Tumor necrosis factor (ligand) } \\
\text { superfamily, member I3b }\end{array}$ & 1 & 0.37 & -1.45 & $\downarrow$ & $\begin{array}{c}\text { Proliferation and } \\
\text { differentiation of } B \text { cells }\end{array}$ \\
\hline VEGFA & Vascular endothelial growth factor $A$ & 1 & 0.50 & -1.00 & $\downarrow$ & \\
\hline IFNA2 & Interferon, alpha 2 & 1 & 0.10 & -3.35 & $\downarrow$ & $\begin{array}{l}\text { Antiviral, antiproliferative and } \\
\text { immunomodulatory properties }\end{array}$ \\
\hline FASLG & $\begin{array}{l}\text { Fas ligand (TNF superfamily, } \\
\text { member } 6)\end{array}$ & 1 & 0.16 & -2.63 & $\downarrow$ & \\
\hline LTA & $\begin{array}{c}\text { Lymphotoxin alpha (TNF superfamily, } \\
\text { member I) }\end{array}$ & 1 & 0.17 & -2.56 & $\downarrow$ & $\begin{array}{c}\text { Inflammatory, } \\
\text { immunostimulatory, and } \\
\text { antiviral responses }\end{array}$ \\
\hline TNF & Tumor necrosis factor & I & 0.16 & -2.65 & $\downarrow$ & Pro-inflammatory properties \\
\hline
\end{tabular}

Notes: $*=$ Upregulation. $*$ = Downregulation.

DBMSCs were treated with $10 \mu \mathrm{g} / \mathrm{mL}$ LPS $(p<0.05)$ and compared to the untreated DBMSCS for $72 \mathrm{~h}$. 

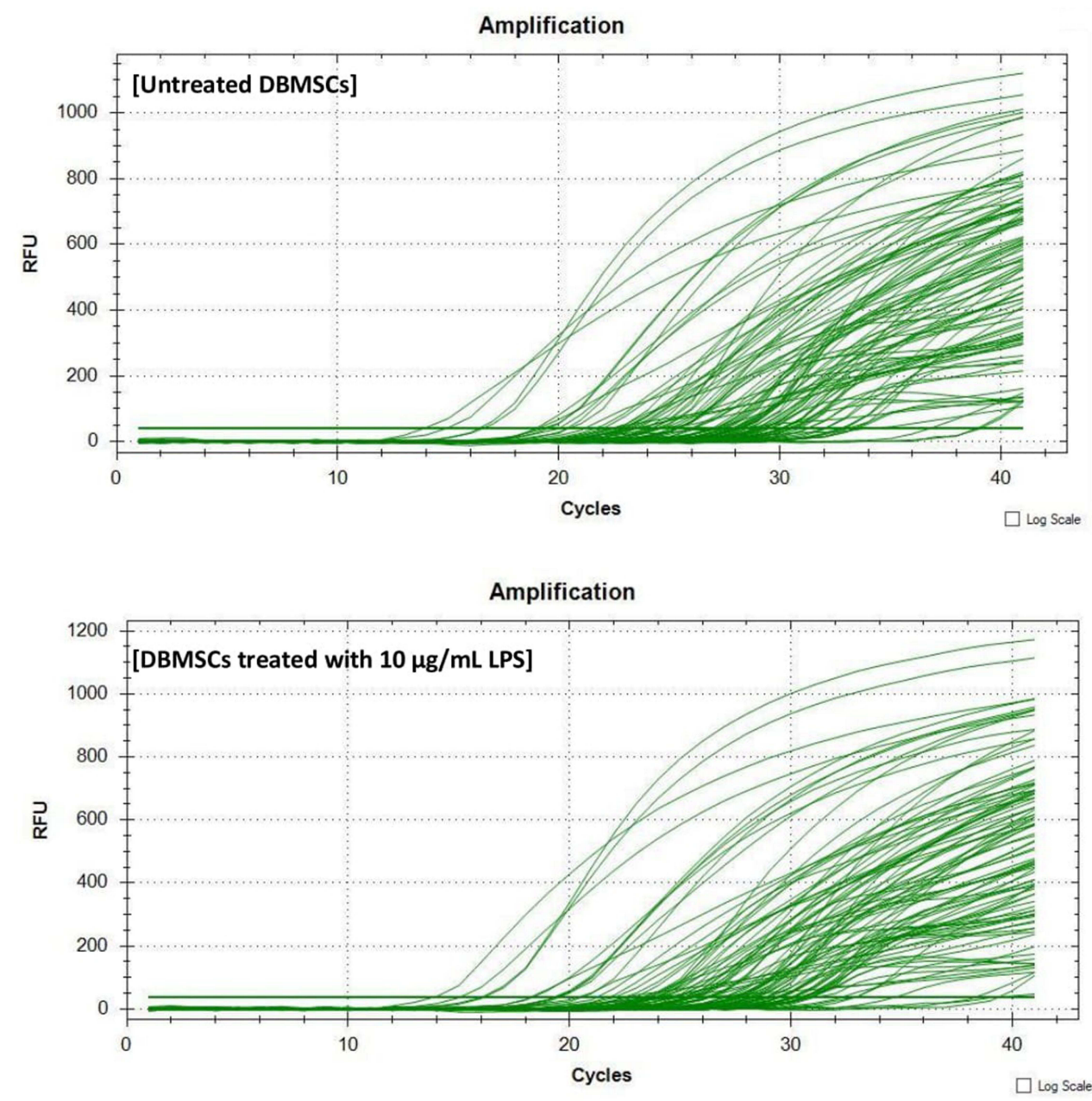

Figure 5 RT-PCR amplification curve of the untreated DBMSCs vs DBMSCs treated with $10 \mu \mathrm{g} / \mathrm{mL}$ LPS (generated by CFX-96 Real-Time System). Experiments were performed three times independently, and the data are represented as mean.

could be the reason why these results did not correlate. Yet, chemokines and receptors are important because they trigger chemokine ligands, such as, CXCL3, and CXCL5 were sig- factors at the site of inflammation; and with the aid of cell nificantly overexpressed in the current study. These adhesion molecules, they contribute to the mobilization and

Table 4 Overexpressed Cytokines and Receptors That are Responsible for DBMSC Functions (Migration, Proliferation, Differentiation) in the Presence of LPS

\begin{tabular}{|c|c|c|c|c|c|c|c|}
\hline \multirow{2}{*}{$\begin{array}{l}\text { Gene } \\
\text { CXCLIO }\end{array}$} & \multicolumn{2}{|c|}{$\begin{array}{l}\text { Fold Change Control vs } 10 \mu g / \\
\text { mL LPS }(p<0.05)\end{array}$} & \multirow{2}{*}{$\begin{array}{c}\text { Biological Activity } \\
\text { Migration }\end{array}$} & \multirow{2}{*}{$\begin{array}{l}\text { Gene } \\
\text { CXCL5 }\end{array}$} & \multicolumn{2}{|c|}{$\begin{array}{l}\text { Fold Change Control vs I0 } \mu \mathrm{g} / \\
\mathrm{mL} \text { LPS }(p<0.05)\end{array}$} & \multirow{2}{*}{$\begin{array}{c}\text { Biological Activity } \\
\text { Migration }\end{array}$} \\
\hline & 13.05 & $\uparrow^{*}$ & & & 0.27 & $\uparrow$ & \\
\hline CX3CRI & 9.21 & $\uparrow$ & Migration & CXCRI & 0.12 & $\uparrow$ & Migration \\
\hline CCLI7 & 4.2 & $\uparrow$ & Migration & IL9 & 20.66 & $\uparrow$ & Proliferation \\
\hline CXCLI & 3.97 & $\uparrow$ & Migration & ILIB & 2.1 & $\uparrow$ & Proliferation \\
\hline CXCLII & 2.55 & $\uparrow$ & Migration & BMP2 & 3.12 & $\uparrow$ & Differentiation \\
\hline CCL23 & 2.35 & $\uparrow$ & Migration & & & $\uparrow$ & \\
\hline CXCL2 & 2.05 & $\uparrow$ & Migration & & & $\uparrow$ & \\
\hline CCR4 & 1.64 & $\uparrow$ & Migration & & & $\uparrow$ & \\
\hline CXCL3 & 1.05 & $\uparrow$ & Migration & & & $\uparrow$ & \\
\hline
\end{tabular}

Note: $*=$ Upregulation. 


\section{Fold Change of Overexpressed Genes: \\ Control vs. DBMSCs $+10 \mu \mathrm{g} / \mathrm{mL}$ LPS \\ $(p<0.05)$}

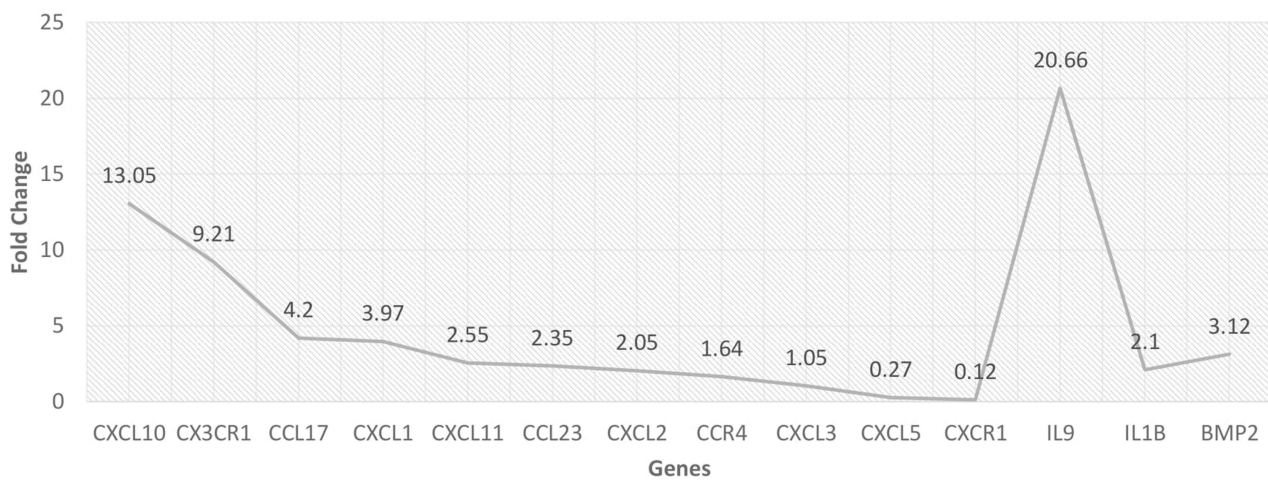

Figure 6 Overexpressed cytokines and receptors that are responsible for DBMSC functions (migration, proliferation, differentiation) in the presence of LPS. Experiments were performed three times independently, and the data are represented as mean.

migration of MSCs to the target tissues. ${ }^{91-96}$ However, to investigate the mechanism of migration of DBMSCs in the presence of LPS will be investigated in a later study.

Upon MSCs' recruitment to the sites of the injury or the target tissues, MSCs secrete several mediators to initiate tissue repair and regeneration, such as anti-inflammatory, anti-apoptotic, immunomodulatory, and other agents. Both anti-inflammatory and immunomodulatory have a significant and main role in the therapeutic aspects of MSCs' application in clinical settings. ${ }^{99-101}$ MSCs also modulate and regulate soluble factors that are related to immune responses, such as PGE2, TGF- $\beta$, IL-6, hepatocyte growth factor (HGF), or others. ${ }^{14,102-104}$ Results showed that DBMSCs treated with $10 \mu \mathrm{g} / \mathrm{mL}$ of LPS overexpressed certain interleukins and receptors. Du-Rocher et al found in their study through using chip array analysis that IL-17 signaling pathway is the second important pathways in MSCs. ${ }^{105}$ Moreover, IL17 is linked to other pro-inflammatory cytokines (IFN $\gamma$ and $\mathrm{TNF} \alpha$ ) that promote the secretion of other chemokines, such as IL-6, IL-8, ICAM-1, and PGE2. ${ }^{106-109}$ In their study, IL-

Table 5 Downregulated Cytokines and Receptors That are Responsible for DBMSCs' Migration and Other Genes That are Not Necessarily Related to DBMSCs Functions in the Presence of LPS

\begin{tabular}{|l|c|c|c|c|c|c|c|}
\hline Gene & \multicolumn{2}{|c|}{$\begin{array}{c}\text { Fold } \\
\text { Change }\end{array}$} & Biological Activity & Gene & \multicolumn{2}{|c|}{$\begin{array}{c}\text { Fold } \\
\text { Change }\end{array}$} & Biological Activity \\
\hline CXCLI2 & -3.2 & $\downarrow^{*}$ & Migration & IL27 & -2.44 & $\downarrow$ & Pro- and anti-inflammatory properties \\
\hline CXCR2 & -3.16 & $\downarrow$ & Migration & IL5 & -3.08 & $\downarrow$ & B cells and eosinophils growth and differentiation \\
\hline CCLI3 & -2.52 & $\downarrow$ & $\begin{array}{c}\text { Immunoregulatory and inflammatory } \\
\text { processes }\end{array}$ & IFNA2 & -3.35 & $\downarrow$ & $\begin{array}{c}\text { Antiviral, antiproliferative and immunomodulatory } \\
\text { properties }\end{array}$ \\
\hline CCL20 & -2.62 & $\downarrow$ & $\begin{array}{c}\text { Immunoregulatory and inflammatory } \\
\text { processes }\end{array}$ & LTA & -2.56 & $\downarrow$ & $\begin{array}{c}\text { Inflammatory, immunostimulatory, and antiviral } \\
\text { responses }\end{array}$ \\
\hline CCLII & -5.08 & $\downarrow$ & Anti-inflammatory & TNF & -2.65 & $\downarrow$ & Pro-inflammatory properties \\
\hline CXCLI3 & -5.47 & $\downarrow$ & B Lymphocyte Chemoattractant & & & $\downarrow$ & $\downarrow$ \\
\hline CXCL9 & -2.77 & $\downarrow$ & $\begin{array}{c}\text { Immunoregulatory and inflammatory } \\
\text { processes }\end{array}$ & & & & \\
\hline ILI5 & -3.02 & $\downarrow$ & $\begin{array}{r}\text { Tand natural killer cell activation and } \\
\text { proliferation }\end{array}$ & & & $\downarrow$ & \\
\hline
\end{tabular}

Note: $*=$ Downregulation 


\section{Fold Change of Downregulated Genes:}

Control vs. DBMSCs $+10 \mu \mathrm{g} / \mathrm{mL}$ LPS

$(p<0.05)$

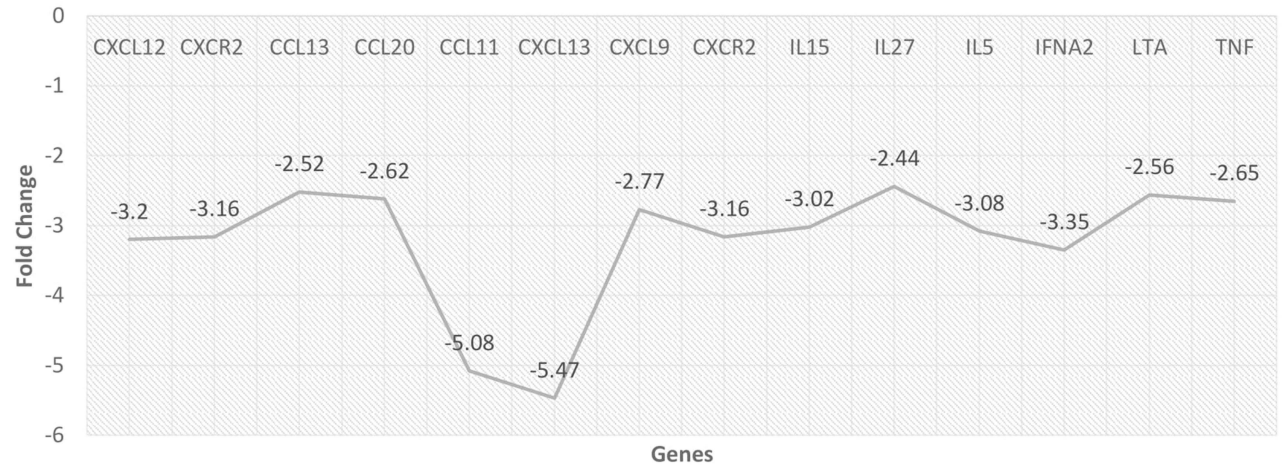

Figure 7 Downregulated cytokines and receptors that are responsible of DBMSCs migration and other genes that are not necessarily related to DBMSC functions in the presence of LPS. Experiments were performed three times independently, and the data are represented as mean.

17 yielded large amounts of IL- 8 and IL- $6 .{ }^{105}$ In the current study, IL-17A was overexpressed when DBMSCs were treated with $10 \mu \mathrm{g} / \mathrm{mL}$ of LPS. IL-8 was also overexpressed in the presence of LPS. These findings correlate to a study conducted by Durand et al. ${ }^{84}$ The authors evaluated the effect of certain factors, such as LPS on BMSC secretomes and they found that BMSCs secretory capacity was increased in the presence of LPS, such as IL-17A and IL- $8 .{ }^{84}$ Other soluble factors were overexpressed when DBMSCs were under continual exposure of $10 \mu \mathrm{g} / \mathrm{mL}$ LPS, such as BMP2. Our result correlated to a study in which the authors tested the effect of exosomes derived from human LPS-activated monocytes on MSCs osteogenic gene expression and found that BMP-2 was significantly increased. ${ }^{110}$ The BMP family which consists of 15 members can promote MSCs' differentiation into several lineages and that depends on the microenvironment concentrations. Each member of BMP family will promote MSCs' differentiation to certain lineages. For instance, BMP-2, BMP-4, and BMP-7 can promote MSCs' differentiation to adipogenic lineage. BMP-2, BMP-6, and BMP-9 can modulate MSCs' differentiation to osteogenic lineage. Lastly, BMP-2 and BMP-7 can promote MSCs to differentiate into chondrogenic lineage. ${ }^{111,112}$ The functional aspect of immune modulation of DBMSCs preconditioned with LPS will be determined in a future study.

These results and findings were in accordance with several studies on MSCs' functional responses and gene expression of cytokines and receptors when treated with several oxidative stress inducers. These results are evident for the potential use of DBMSCS as a therapeutic agent for the treatment of inflammatory diseases, such as atherosclerosis since DBMSCs survived in harsh environments that were induced by high levels of LPS.

\section{Conclusion}

In conclusion, DBMSCs have potential functional properties that enhance their application in cell-based therapy because of their abilities to work in highly oxidative stress environments as they maintained their functional activities when treated with $\mathrm{H}_{2} \mathrm{O}_{2}$ and monocytes. ${ }^{23}$ LPS is another form of inflammatory environment condition. Results of this study indicated that DBMSCs' functions (adherence, proliferation, and migration) were not significantly affected $(p>0.05)$ when DBMSCs were treated with continuous exposures of different concentrations $(0.50,1,10,50,100$, $200 \mu \mathrm{g} / \mathrm{mL}$ ) of LPS (Figure 8). No variation between treated DBMSCs and the control group indicated that DBMSCs can survive in pro-inflammatory condition, in the presence of LPS, and can maintain their functional activities (adherence, proliferation, and migration). Moreover, many chemokines and receptors that are related to DBMSCs' phenotypic properties, such as adherence, proliferation, differentiation, and migration were overexpressed when DBMSCs have been subjected to $10 \mu \mathrm{g} / \mathrm{mL}$ of LPS. Nevertheless, future in vitro and in vivo studies on DBMSCs are necessary to assess the potential use of DBMSCs in treating inflammatory diseases. For instance, DBMSCs' ability to invade endothelial tissues or layers in LPS condition and time- 


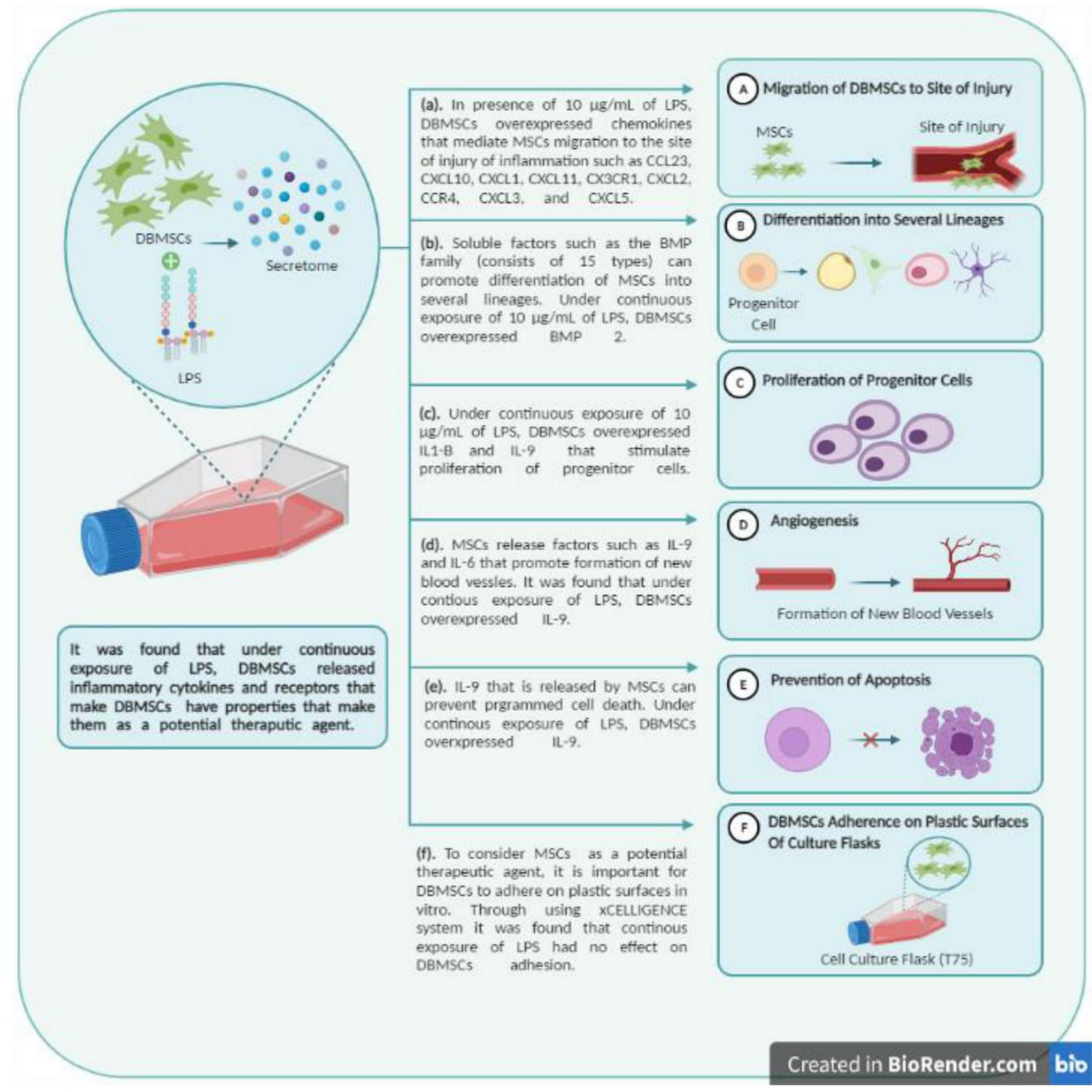

Figure 8 The effect of LPS on DBMSCs' functional responses (proliferation, adhesion, and migration) (Created with BioRender.com).

related phenotype changes of DBMSCs in the presence of continuous exposure to LPS. Evaluating the functional responses of DBMSCs when preconditioned with LPS will be investigated in future studies.

\section{Acknowledgments}

This research was funded by the Deanship of Scientific Research at Princess Nourah Bint Abdulrahman University, through the Pioneer Researcher Funding Program (Grant No\# PR-1441-4) and King Abdullah International Medical
Research Center for providing the supervion and facilities to support the study.

\section{Disclosure}

The authors report no conflicts of interest in this work.

\section{References}

1. Shin JH, Ryu CM, Yu HY, Shin DM, Choo MS. Current and future directions of stem cell therapy for bladder dysfunction. Stem Cell Rev Rep. 2020;16(1):82-93. 
2. Bae SH. Recent achievements in stem cell therapy for pediatric gastrointestinal tract disease. Pediatr Gastroenterol Hepatol Nutr. 2013;16(1):10-16. doi:10.5223/pghn.2013.16.1.10

3. Quante M, Wang TC. Stem cells in gastroenterology and hepatology. Nat Rev Gastroenterol Hepatol. 2009;6(12):724. doi:10.1038/nrgastro.2009.195

4. Van Der Flier LG, Clevers H. Stem cells, self-renewal, and differentiation in the intestinal epithelium. Annu Rev Physiol. 2009;71:241-260. doi:10.1146/annurev.physiol.010908.163145

5. Ratajczak M, Suszynskan M, Pedziwiatr D, Mierzejewska K, Greco N. Umbilical cord blood-derived very small embryonic like stem cells (VSELs) as a source of pluripotent stem cells for regenerative medicine. Pediatr Endocrinol Rev. 2012;9 (3):639-643.

6. Chu DT, Nguyen TT, Tien NLB, et al. Recent progress of stem cell therapy in cancer treatment: molecular mechanisms and potential applications. Cells. 2020;9(3):563. doi:10.3390/ cells9030563

7. Ghafarzadeh M, Namdari P, Tarhani M, Tarhani F. A review of application of stem cell therapy in the management of Congenital Heart Disease. J Matern Fetal Neonatal Med. 2020;33 (9):1607-1615.

8. Heo JS, Choi Y, Kim HS, Kim HO. Comparison of molecular profiles of human mesenchymal stem cells derived from bone marrow, umbilical cord blood, placenta and adipose tissue. Int J Mol Med. 2015;37:115-125. doi:10.3892/ijmm.2015.2413

9. Elahi KC, Klein G, Avci-Adali M, Sievert KD, Macneil S, Aicher WK. Human mesenchymal stromal cells from different sources diverge in their expression of cell surface proteins and display distinct differentiation patterns. Stem Cells Int. 2016;2016:1-9. doi:10.1155/2016/5646384

10. Nancarrow-Lei R, Mafi P, Mafi R, Khan W. A systemic review of adult mesenchymal stem cell sources and their multilineage differentiation potential relevant to musculoskeletal tissue repair and regeneration. Curr Stem Cell Res. 2017;12:601-610.

11. Olson TS, Ley K. Chemokines and chemokine receptors in leukocyte trafficking. Am J Physiol Regul Integr Comp Physiol. 2002;283(1):R7-R28. doi:10.1152/ajpregu.00738.2001

12. Gnecchi M, Zhang Z, Ni A, Dzau VJ. Paracrine mechanisms in adult stem cell signaling and therapy. Circ Res. 2008;103 (11):1204-1219. doi:10.1161/CIRCRESAHA.108.176826

13. Meirelles LDS, Chagastelles PC, Nardi NB. Mesenchymal stem cells reside in virtually all post-natal organs and tissues. $J$ Cell Sci. 2006;119:2204-2213. doi:10.1242/jcs.02932

14. Chen K, Wang D, Du WT, et al. Human umbilical cord mesenchymal stem cells hUC-MSCs exert immunosuppressive activities through a PGE2-dependent mechanism. Clin Immunol. 2010;135:448-458. doi:10.1016/j.clim.2010.01.015

15. Nitzsche F, Müller C, Lukomska B, Jolkkonen J, Deten A, Boltze J. Concise review: MSC adhesion cascade-insights into homing and transendothelial migration. Stem Cells. 2017;35:1446-1460. doi:10.1002/stem.2614

16. Friedenstein AJ, Chailakhjan RK, Lalykina KS. The development of fibroblast colonies in monolayer cultures of Guinea pig bone marrow and spleen cells. Cell Prolif. 1970;3:393-403. doi:10.1111/j.1365-2184.1970.tb00347.x

17. Wagers AJ, Weissman IL. Plasticity of adult stem cells. Cell. 2004;116(5):639-648. doi:10.1016/S0092-8674(04)00208-9

18. Bianco P, Cao X, Frenette PS, et al. The meaning, the sense and the significance: translating the science of mesenchymal stem cells into medicine. Nat Med. 2013;19(1):35-42. doi:10.1038/ nm. 3028

19. Abomaray FM, Al Jumah MA, Alsaad KO, et al. Phenotypic and functional characterization of mesenchymal stem/multipotent stromal cells from decidua basalis of human term placenta. Stem Cells Int. 2016;2016:1-18. doi:10.1155/2016/5184601
20. Ding DC, Shyu WC, Lin SZ. Mesenchymal stem cells. Cell Transplant. 2011;20(1):5-14. doi:10.3727/096368910X

21. Huang YC, Yang ZM, Chen XH, et al. Isolation of mesenchymal stem cells from human placental decidua basalis and resistance to hypoxia and serum deprivation. Stem Cell Rev. 2009;5:247-255. doi:10.1007/s12015-009-9069-x

22. Kusuma GD, Abumaree MH, Pertile MD, Perkins AV, Brennecke SP, Kalionis B. Mesenchymal stem/stromal cells derived from a reproductive tissue niche under oxidative stress have high aldehyde dehydrogenase activity. Stem Cell Rev Rep. 2016;12(3):285-297. doi:10.1007/s12015-016-9649-5

23. Alshabibi MA, Khatlani T, Abomaray FM, et al. Human decidua basalis mesenchymal stem/stromal cells protect endothelial cell functions from oxidative stress induced by hydrogen peroxide and monocytes. Stem Cell Res Ther. 2018;9(1). doi:10.1186/s13287018-1021-z

24. Khatlani T, Algudiri D, Alenzi R, et al. Preconditioning by hydrogen peroxide enhances multiple properties of human decidua basalis mesenchymal stem/multipotent stromal cells. Stem Cells Int. 2018;2018:1-13. doi:10.1155/2018/6480793

25. Alshabibi MA, Al Huqail AJ, Khatlani T, et al. Mesenchymal stem/multipotent stromal cells from human decidua basalis reduce endothelial cell activation. Stem Cells Dev. 2017;26:1355-1373. doi:10.1089/scd.2017.0096

26. De Nardin E. The role of inflammatory and immunological mediators in periodontitis and cardiovascular disease. Ann Periodontol. 2001;6:30-40. doi:10.1902/annals.2001.6.1.30

27. Kuramitsu HK, Kang IC, Qi M. Interactions of Porphyromonas gingivalis with host cells: implications for cardiovascular diseases. J Periodontol. 2003;74:85-89. doi:10.1902/ jop.2003.74.1.85

28. Li L, Messas E, Batista EL Jr, Levine RA, Amar S. Porphyromonas gingivalis infection accelerates the progression of atherosclerosis in a heterozygous apolipoprotein E-deficient murine model. Circulation. 2002;105:861-867. doi:10.1161/ hc0702.104178

29. Horseman MA, Surani S, Bowman JD. Endotoxin, toll-like receptor-4, and atherosclerotic heart disease. Curr Cardiol Rev. 2017;13(2):81-93.

30. Nikaido H. Molecular basis of bacterial outer membrane permeability revisited. Microbiol Mol Biol Rev. 2003;67:593-656.

31. Rietschel ET, Kirikae T, Schade FU, et al. Bacterial endotoxin: molecular relationships of structure to activity and function. FASEB J. 1994;8:217-225. doi:10.1096/fasebj.8.2.8119492

32. Raetz CR, Whitfield C. Lipopolysaccharide endotoxins. Annu Rev Biochem. 2002;71:635-700. doi:10.1146/annurev.biochem.71.110 601.135414

33. Goto T, Eden S, Nordenstam G, Sundh V, Svanborg-Eden C, Mattsby-Baltzer I. Endotoxin levels in sera of elderly individuals. Clin Diagn Lab Immunol. 1994;1:684-688. doi:10.1128/cdli.1.6.684-688.1994

34. Niebauer J, Volk HD, Kemp M, et al. Endotoxin and immune activation in chronic heart failure: a prospective cohort study. Lancet. 1999;353:1838-1842. doi:10.1016/S0140-6736(98)09286-1

35. Wiedermann CJ, Kiechl S, Dunzendorfer S, et al. Association of endotoxemia with carotid atherosclerosis and cardiovascular disease: prospective results from the Bruneck Study. J Am Coll Cardiol. 1999;34:1975-1981. doi:10.1016/S0735-1097(99) 00448-9

36. Kiechl S, Egger G, Mayr M, et al. Chronic infections and the risk of carotid atherosclerosis: prospective results from a large population study. Circulation. 2001;103(8):1064-1070. doi:10.1161/ 01.CIR.103.8.1064

37. Cani PD, Amar J, Iglesias MA. Metabolic endotoxemia initiates obesity and insulin resistance. Diabetes. 2007;56(7):1761-1772. doi: $10.2337 / \mathrm{db} 06-1491$ 
38. Applebaum KM, Ray RM, Astrakianakis G. Evidence of a paradoxical relationship between endotoxin and lung cancer after accounting for left truncation in a study of Chinese female textile workers. Occup Environ Med. 2013;70(10):709-715. doi:10.1136/oemed-2012-101240

39. Jeon D, Kim SJ, Kim HS. Anti-inflammatory evaluation of the methanolic extract of Taraxacum officinale in LPS-stimulated human umbilical vein endothelial cells. BMC Complement Altern Med. 2017;17(1). doi:10.1186/s12906-017-2022-7

40. Ross R. Atherosclerosis-an inflammatory disease. $N$ Engl J Med. 1999;340(2):115-126. doi:10.1056/NEJM199901143400207

41. Libby P. Inflammation in atherosclerosis. Arterioscler Thromb Vasc Biol. 2012;32(9):2045-2051. doi:10.1161/ATVBAHA.108.179705

42. Pfeffer R, Ganatos P, Nir A, Weinbaum S. Diffusion of macromolecules across the arterial wall in the presence of multiple endothelial injuries. $J$ Biomech Eng. 1981;103:197-203. doi: $10.1115 / 1.3138278$

43. Stoll LL, Denning GM, Weintraub NL. Potential role of endotoxin as a proinflammatory mediator of atherosclerosis. Arterioscler Thromb Vasc Biol. 2004;24:2227-2236. doi:10.1161/01.ATV.0000147534.69062.dc

44. Weinbaum S, Tzeghai G, Ganatos P, Pfeffer R, Chien S. Effect of cell turnover and leaky junctions on arterial macromolecular transport. Am J Physiol. 1985;248:H945-960.

45. Lehr HA, Sagban TA, Ihling C, et al. Immunopathogenesis of atherosclerosis: endotoxin accelerates atherosclerosis in rabbits on hypercholesterolemic diet. Circulation. 2001;104:914-920. doi:10.1161/hc3401.093153

46. Ostos MA, Recalde D, Zakin MM, Scott-Algara D. Implication of natural killer $\mathrm{T}$ cells in atherosclerosis development during a LPS-induced chronic inflammation. FEBS Lett. 2002;519:23-29. doi:10.1016/S0014-5793(02)02692-3

47. Rice JB, Stoll LL, Li WG, et al. Low-level endotoxin induces potent inflammatory activation of human blood vessels: inhibition by statins. Arterioscler Thromb Vasc Biol. 2003;23:1576-1582. doi:10.1161/01.ATV.0000081741.38087.F9

48. Ghanim H, Sia CL, Upadhyay M, et al. Orange juice neutralizes the proinflammatory effect of a high-fat, high-carbohydrate meal and prevents endotoxin increase and Toll-like receptor expression. Am J Clin Nutr. 2010;91(4):940-949. doi:10.3945/ ajen.2009.28584

49. Laugerette FC, Vors A, Geloen A. Emulsified lipids increase endotoxemia: possible role in early postprandial low-grade inflammation. J Nutr Biochem. 2011;22(1):53-59. doi:10.1016/j. jnutbio.2009.11.011

50. Abumaree MH, Abomaray FM, Alshabibi MA, AlAskar AS, Kalionis B. Immunomodulatory properties of human placental mesenchymal stem/ stromal cells. Placenta. 2017;59:87-95. doi:10.1016/j.placenta.2017.04.003

51. Abumaree MH, Hakami M, Abomaray FM, et al. Human chorionic villous mesenchymal stem/stromal cells modify the effects of oxidative stress on endothelial cell functions. Placenta. 2017;59:74-86. doi:10.1016/j.placenta.2017.05.001

52. Basmaeil YS, Al Subayyil AM, Khatlani T, et al. Human chorionic villous mesenchymal stem/stromal cells protect endothelial cells from injury induced by high level of glucose. Stem Cell Res Ther. 2018;9:238. doi:10.1186/s13287-018-0984-0

53. Uccelli A, Moretta L, Pistoia V. Mesenchymal stem cells in health and disease. Nat Rev Immunol. 2008;8:726-736. doi:10.1038/ nri2395

54. Wei X, Yang X, Han ZP, Qu FF, Shao L, Shi YF. Mesenchymal stem cells: a new trend for cell therapy. Acta Pharmacol Sin. 2013;34:747-754. doi:10.1038/aps.2013.50

55. Squillaro T, Peluso G, Galderisi U. Clinical trials with mesenchymal stem cells: an update. Cell Transplant. 2016;25:829-848. doi: $10.3727 / 096368915 \times 689622$
56. Lee KD, Kuo TK, Whang-Peng J, et al. In vitro hepatic differentiation of human mesenchymal stem cells. Hepatology. 2004;40 (6):1275-1284. doi:10.1002/hep.20469

57. Paunescu V, Deak E, Herman D, Siska IR, Tanasie G, Bunu C. In vitro differentiation of human mesenchymal stem cells to epithelial lineage. J Cell Mol Med. 2007;11:502-508. doi:10.1111/ j.1582-4934.2007.00041.x

58. Quevedo HC, Hatzistergos KE, Oskouei BN, Feigenbaum GS, Rodriguez JE, Valdes D. Allogeneic mesenchymal stem cells restore cardiac function in chronic ischemic cardiomyopathy via trilineage differentiating capacity. Proc Natl Acad Sci. 2009;106:14022-14027. doi:10.1073/pnas.0903201106

59. Friedenstein AJ, Piatetzky-Shapiro II, Petrakova KV. Osteogenesis in transplants of bone marrow cells. J Embryol Exp Morphol. 1966;16:381-390.

60. Ullah I, Subbarao RB, Rho GJ. Human mesenchymal stem cells - current trends and future prospective. Biosci Rep. 2015;28:35.

61. Salgado AJ, Reis RL, Sousa NJ, Gimble JM. Adipose tissue derived stem cells secretome: soluble factors and their roles in regenerative medicine. Curr Stem Cell Res Ther. 2010;5:103-110. doi:10.2174/157488810791268564

62. Jimenez-Puerta GJ, Marchal JA, López-Ruiz E, Gálvez-Martín P. Role of mesenchymal stromal cells as therapeutic agents: potential mechanisms of action and implications in their clinical use. $J$ Clin Med. 2020;9(2):445th ser. doi:10.3390/jcm9020445

63. Kot M, Musiał-Wysocka A, Lasota M, Ulman A, Majka M. Secretion, migration and adhesion as key processes in the therapeutic activity of mesenchymal stem cells. Acta Biochim Pol. 2019;66(4):499-507.

64. Sotiropoulou PA, Perez SA, Salagianni M, Baxevanis CN, Papamichail M. Characterization of the optimal culture conditions for clinical scale production of human mesenchymal stem cells. Stem Cells. 2006;24:462-471. doi:10.1634/stemcells.2004-0331

65. Lee KA, Shim W, Paik MJ, et al. Analysis of changes in the viability and gene expression profiles of human mesenchymal stromal cells over time. Cytotherapy. 2009;11(6):688-697. doi: $10.3109 / 14653240902974032$

66. Schoeberlein A, Mueller M, Reinhart U, Sager R, Messerli M, Surbek DV. Homing of placenta-derived mesenchymal stem cells after perinatal intracerebral transplantation in a rat model. Am $J$ Obstet Gynecol. 2011;205(277):e1-e6. doi:10.1016/j. ajog.2011.06.044

67. Fossett E, Khan W. Optimising human mesenchymal stem cell numbers for clinical application: a literature review. Stem Cells Int. 2012;2012:1-5. doi:10.1155/2012/465259

68. Francois S, Mouiseddine M, Allenet-Lepage B. Human mesenchymal stem cells provide protection against radiation-induced liver injury by antioxidative process, vasculature protection, hepatocyte differentiation, and trophic effects. Biomed Res Int. 2013;2013:1-14. doi:10.1155/2013/151679

69. Halabian R, Tehrani HA, Jahanian-Najafabadi A, Roudkenar MH. Lipocalin-2-mediated upregulation of various antioxidants and growth factors protects bone marrow derived mesenchymal stem cells against unfavorable microenvironments. Cell Stress Chaperones. 2013;18:785-800. doi:10.1007/s12192-013-0430-2

70. Han SM, Han SH, Coh YR. Enhanced proliferation and differentiation of Oct4-and Sox2-overexpressing hu man adipose tissue mesenchymal stem cells. Exp Mol Med. 2014;46:e101. doi:10.1038/emm.2014.28

71. Amiri F, Jahanian-Najafabadi A, Roudkenar MH. In vitro augmentation of mesenchymal stem cells viability in stressful microenvironments. Cell Stress Chaperones. 2015;20:237-251. doi:10.1007/s12192-014-0560-1

72. Hagberg H, Mallard C, Ferriero DM. The role of inflammation in perinatal brain injury. Nat Rev Neurol. 2015;11:192. doi:10.1038/ nrneurol.2015.13 
73. Mueller M, Wolfs TG, Schoeberlein A, Gavilanes AW, Surbek D, Kramer BW. Mesenchymal stem/ stromal cells - a key mediator for regeneration after perinatal morbidity. Mol Cell Pediatr. 2016;3:6. doi:10.1186/s40348-016-0034-x

74. Raijmakers MT, Roes EM, Poston L, Steegers EA, Peters WH. The transient increase of oxidative stress during normal pregnancy is higher and persists after delivery in women with pre-eclampsia. Eur J Obstet Gynecol Reprod Biol. 2008;138 (1):39-44. doi:10.1016/j.ejogrb.2007.08.005

75. Ashok A, Nabil A, Botros R. Studies on Women's Health: Oxidative Stress in Applied Basic Research and Clinical Practice. Agarwal A, Aziz N, Rizk B, editors. New York: Humana Press; 2013.

76. Basmaeil Y, Rashid MA, Khatlani T, et al. Preconditioning of human decidua basalis mesenchymal stem/stromal cells with glucose increased their engraftment and anti-diabetic properties. Tissue Eng Regen Med. 2020;17(2):209.

77. Dominici M, Le Blanc K, Mueller I, et al. Minimal criteria for defining multipotent mesenchymal stromal cells. The International Society for Cellular Therapy position statement. Cytotherapy. 2006;8(4):315-317.

78. Peterson KM, Aly A, Lerman A, Lerman LO, Rodriguez-Porcel M. Improved survival of mesenchymal stromal cell after hypoxia preconditioning: role of oxidative stress. Life Sci. 2011;88(12):65-73. doi:10.1016/j.lfs.2010.10.023

79. Lai P, Li T, Yang J, et al. Upregulation of stromal cell-derived factor 1 (SDF-1) expression in microvasculature endothelial cells in retinal ischemia-reperfusion injury. Graefes Arch Clin Exp Ophthalmol. 2008;246(12):1707-1713. doi:10.1007/s00417-0080907-3

80. Richmond A. Chemokine modulation of the tumor microenvironment. Pigment Cell Melanoma Res. 2010;23 (3):312-313. doi:10.1111/j.1755-148X.2010.00714.X

81. Silva LHA, Antunes MA, Dos Santos CC, Weiss DJ, Cruz FF, Rocco PRM. Strategies to improve the therapeutic effects of mesenchymal stromal cells in respiratory diseases. Stem Cell Res Ther. 2018;9(1):45. doi:10.1186/s13287-018-0802-8

82. Zhao L, Hu C, Han F, Cai F, Wang J, Chen J. Preconditioning is an effective strategy for improving the efficiency of mesenchymal stem cells in kidney transplantation. Stem Cell Res Ther. 2020;11 (1):197. doi:10.1186/s13287-020-01721-8

83. Kurte M, Vega-Letter AM, Luz-Crawford $P$, et al. Timedependent LPS exposure commands MSC immunoplasticity through TLR4 activation leading to opposite therapeutic outcome in EAE. Stem Cell Res Ther. 2020;11(1). doi:10.1186/s13287020-01840-2

84. Durand N, Russell A, Zubair AC. Effect of comedications and endotoxins on mesenchymal stem cell secretomes, migratory and immunomodulatory capacity. J Clin Med. 2019;8(4):497. doi: $10.3390 / \mathrm{jcm} 8040497$

85. Goswami R, Kaplan MH. A brief history of IL-9. J Immunol. 2011;186:3283-3288. doi:10.4049/jimmunol.1003049

86. Sun Y, Liu S, Hu R, Zhou Q, Li X. Decreased placental IL9 and IL9R in preeclampsia impair trophoblast cell proliferation, invasion, and angiogenesis. Hypertens Pregnancy. 2020;39 (3):228-235

87. Bigildeev AE, Zezina EA, Shipounova IN, Drize NJ. Interleukin1 beta enhances human multipotent mesenchymal stromal cell proliferative potential and their ability to maintain hematopoietic precursor cells. Cytokine. 2015;71(2):246-254. doi:10.1016/j. cyto.2014.10.018

88. Matsumura E, Tsuji K, Komori K, Koga H, Sekiya I, Muneta T. Pretreatment with IL-1 $\beta$ enhances proliferation and chondrogenic potential of synovium-derived mesenchymal stem cells. Cytotherapy. 2017;19(2):181-193. doi:10.1016/j.jcyt.2016.11.004
89. Amann EM, Groß A, Rojewski MT, et al. Inflammatory response of mesenchymal stromal cells after in vivo exposure with selected trauma-related factors and polytrauma serum. PLoS One. 2019;14 (5):e0216862. doi:10.1371/journal.pone.0216862

90. Cui TX, Brady AE, Fulton CT, et al. CCR2 mediates chronic LPS-induced pulmonary inflammation and hypoalveolarization in a murine model of bronchopulmonary dysplasia. Front Immunol. 2020;11. doi:10.3389/fimmu.2020.579628

91. Wynn RF, Hart CA, Corradi-Perini C, O’Neill L, Evans CA, Wraith JE. A small proportion of mesenchymal stem cells strongly expresses functionally active CXCR4 receptor capable of promoting migration to bone marrow. Blood. 2004;104:2643-2645. doi:10.1182/blood-2004-02-0526

92. Sordi V, Malosio ML, Marchesi F, Mercalli A, Melzi R, Giordano T. Bone marrow mesenchymal stem cells express a restricted set of functionally active chemokine receptors capable of promoting migration to pancreatic islets. Blood. 2005;106:419-427. doi:10.1182/blood-2004-09-3507

93. Honczarenko M, Le Y, Swierkowski M, Ghiran I, Glodek AM, Silberstein LE. Human bone marrow stromal cells express a distinct set of biologically functional chemokine receptors. Stem Cells. 2005;24:1030-1041. doi:10.1634/stemcells.2005-0319

94. Von Luttichau I, Notohamiprodjo M, Wechselberger A, Peters C, Henger A, Seliger C. Human adult CD34- progenitor cells functionally express the chemokine receptors CCR1, CCR4, CCR7, CXCR5, and CCR10 but not CXCR4. Stem Cells Dev. 2005;14:329-336. doi:10.1089/scd.2005.14.329

95. Ringe J, Strassburg S, Neumann K, Endres M, Notter M, Burmester GR. Towards in situ tissue repair: human mesenchymal stem cells express chemokine receptors CXCR1. CXCR2 and CCR2, and migrate upon stimulation with CXCL8 but not CCL2. J Cell Biochem. 2007;101:135-146. doi:10.1002/jcb.21172

96. Ma J, Liu N, Yi B, Zhang X, Gao BB, Zhang Y. Transplanted hUCB-MSCs migrated to the damaged area by SDF-1/CXCR4 signaling to promote functional recovery after traumatic brain injury in rats. Neurol Res. 2015;37:50-56. doi:10.1179/ 1743132814Y.0000000399

97. Wobus M, List C, Dittrich T, Dhawan A, Duryagina R, Arabanian LS. Breast carcinoma cells modulate the chemoattractive activity of human bone marrow-derived mesenchymal stromal cells by interfering with CXCL12. Int $J$ Cancer. 2014;136:44-54. doi:10.1002/ijc. 28960

98. Shen Z, Wang J, Huang Q, et al. Genetic modification to induce CXCR2 overexpression in mesenchymal stem cells enhances treatment benefits in radiation-induced oral mucositis. Cell Death Dis. 2018;9(2). doi:10.1038/s41419-018-0310-x

99. Meirelles LDS, Fontes AM, Covas DT, Caplan AI. Mechanisms involved in the therapeutic properties of mesenchymal stem cells. Cytokine Growth Factor Rev. 2009;20:419-427. doi:10.1016/j. cytogfr.2009.10.002

100. Escacena N, Quesada-Hernandez E, Capilla-Gonzalez V, Soria B, Hmadcha A. Bottlenecks in the efficient use of advanced therapy medicinal products based on mesenchymal stromal cells. Stem Cells Int. 2015;2015:895714.

101. Hmadcha A, Martin-Montalvo A, Gauthier BR, Soria B, CapillaGonzalez V. Therapeutic potential of mesenchymal stem cells for cancer therapy. Front Bioeng Biotechnol. 2020;8. doi:10.3389/ fbioe. 2020.00043

102. Di Nicola M, Carlo-Stella C, Magni M, et al. Human bone marrow stromal cells suppress T-lymphocyte proliferation induced by cellular or nonspecific mitogenic stimuli. Blood. 2002;99:3838-3843. doi:10.1182/blood.V99.10.3838

103. Nauta AJ, Kruisselbrink AB, Lurvink E, Willemze R, Fibbe WE. Mesenchymal stem cells inhibit generation and function of both CD34+-derived and monocyte-derived dendritic cells. J Immunol. 2006;177:2080-2087. doi:10.4049/jimmunol.177.4.2080 
104. Nemeth K, Keane-Myers A, Brown JM, et al. Bone marrow stromal cells use TGF-beta to suppress allergic responses in a mouse model of ragweed-induced asthma. Proc Natl Acad Sci. 2010;107:5652-5657. doi:10.1073/pnas.0910720107

105. Du-Rocher B, Binato R, de-freitas-junior JCM, et al. IL-17 triggers invasive and migratory properties in human MSCs, while IFN $\gamma$ favors their immunosuppressive capabilities: implications for the "licensing" process. Stem Cell Rev Rep. 2020;16(6):1266-1279. doi:10.1007/s12015-020-10051-4

106. Albanesi C, Cavani A, Girolomoni G. IL-17 is produced by nickel-specific T lymphocytes and regulates ICAM-1 expression and chemokine production in human keratinocytes: synergistic or antagonist effects with IFN-gamma and TNF-alpha. J Immunol. 1999;162(1):494-502.

107. Eid RE, Rao DA, Zhou J, et al. Interleukin-17 and interferon$\gamma$ are produced concomitantly by human coronary arteryinfiltrating $\mathrm{T}$ cells and act synergistically on vascular smooth muscle cells. Circulation. 2009;119(10):1424-1432. doi:10.1161/CIRCULATIONAHA.108.827618

108. Bulek K, Liu C, Swaidani S, et al. The inducible kinase IKKi is required for IL-17-dependent signaling associated with neutrophilia and pulmonary inflammation. Nat Immunol. 2011;12 (9):844-852. doi:10.1038/ni.2080
109. Gabr MA, Jing L, Helbling AR, et al. Interleukin-17 synergizes with IFN $\gamma$ or TNF $\alpha$ to promote inflammatory mediator release and intercellular adhesion molecule-1 (ICAM-1) expression in human intervertebral disc cells. J Orthop Res. 2011;29(1):1-7. doi:10.1002/jor.21206

110. Ekström K, Omar $\mathrm{O}$, Granéli $\mathrm{C}$, Wang $\mathrm{X}$, Vazirisani $\mathrm{F}$, Thomsen P. Monocyte exosomes stimulate the osteogenic gene expression of mesenchymal stem cells. PLoS One. 2013;8(9): e75227. doi:10.1371/journal.pone.0075227

111. Kang Q, Song WX, Luo Q, et al. A comprehensive analysis of the dual roles of BMPs in regulating adipogenic and osteogenic differentiation of mesenchymal progenitor cells. Stem Cells Dev. 2009;18(4):545-559. doi:10.1089/scd.2008.0130

112. Chen G, Deng C, Li YP. TGF-beta and BMP signaling in osteoblast differentiation and bone formation. Int $J$ Biol Sci. 2012;8:272-288. doi:10.7150/ijbs.2929

\section{Publish your work in this journal}

Stem Cells and Cloning: Advances and Applications is an international, peer-reviewed, open access journal. Areas of interest in established and emerging concepts in stem cell research include: Embryonic cell stems; Adult stem cells; Blastocysts; Cordblood stem cells; Stem cell transformation and culture; Therapeutic cloning; Umbilical cord blood and bone marrow cells; Laboratory, animal and human therapeutic studies; Philosophical and ethical issues related to stem cell research. This journal is indexed on CAS. The manuscript management system is completely online and includes a very quick and fair peer-review system, which is al easy to use. Visit http://www.dovepress.com/testimonials.php to read real quotes from published authors. 